\title{
Las relaciones culturales de España en tiempo de crisis: de la II República a la Guerra Mundial
}

\author{
LoREnzo Delgado Gómez-EscalonilLa
}

\section{LAS RELACIONES CULTURALES EN JULIO DE 1936}

En los primeros meses de 1936 el personal de la Junta de Relaciones Culturales preparaba la memoria correspondiente al año anterior. Se daba continuidad con ella a la difusión de las actividades del organismo, comenzada tras el establecimiento de la II República, y que contaba ya con las publicaciones relativas a los años 1931-1933 y 1934. Esa preocupación por divulgar los resultados de su labor era una muestra más del dinamismo que había adquirido la Junta de Relaciones Culturales después de la reforma que experimentó en 1931. También recordaba a la actuación de la Junta para Ampliación de Estudios, que editaba sistemáticamente las memorias de sus actividades para dejar constancia pública del trabajo realizado. La analogía a este respecto no era casual. Con la república los intelectuales reformistas procedentes de la Institución Libre de Enseñanza, que tiempo atrás inspiraron la creación de la Junta para Ampliación de Estudios, habian recuperado el predicamento sobre la planificación de la política cultural con el extranjero. Pero la memoria de la Junta del año 1935 nunca llegó a aparecer. La guerra civil se cruzó en el camino de quienes la redactaban.

¿Cuál era el estado de esas relaciones culturales antes de que estallase el conflicto? La información recopilada para la elaboración de la memoria aludida nos permite reconstruir el grado de protagonismo que la Junta de Relaciones Culturales había alcanzado en ese ámbito. Sus realizaciones retomaron los ejes de acción propuestos por el profesor Américo Castro en los años veinte, momento en que se creó en el Ministerio de Estado el primer servicio encargado de las relaciones 
culturales con el extranjero, advirtiéndose un triple frente prioritario de actuación '.

En primer lugar, se apreciaba una marcada preocupación hacia la emigración española, hacia la conservación de sus señas de identidad lingüisticas y culturales, que estaba en consonancia a su vez con el impulso educativo emprendido en el interior del pais desde 1931. El saldo era particularmente fecundo en el terreno de la primera enseñanza, con el establecimiento de una red docente que comprendia nueve escuelas españolas en Andorra y Portugal, y veintiuna clases de español en escuelas de Francia y Argelia. Los maestros, además de las tareas docentes propiamente dichas, se ocupaban de otras actividades extra-escolares: la organización de bibliotecas en todos los centros y de sesiones de cine educativo con los libros y el material audiovisual enviados por la Junta de Relaciones Culturales; la realización de viajes anuales a España con grupos de alumnos; el desarrollo paralelo de clases para adultos, y la constitución de Sociedades de Amigos de las Clases en las distintas localidades. En el ámbito de la segunda enseñanza, se había fundado en 1933 el Instituto "Hermenegildo Giner de los Ríos" de Lisboa, dotándosele progresivamente de la misma plantilla de personal docente que tenian los institutos de bachillerato españoles, reconociéndosele la plena validez oficial de sus estudios, y con la pretensión de que llegara a convertirse en un centro cultural de mayor alcance.

En segundo lugar, era patente la atención dedicada al fomento del hispanismo en otros países, para estimular el interés por el conocimiento de la lengua y la civilización españolas. La Junta se hizó cargo de la selección y nombramiento de los lectores de español, antes competencia del Centro de Estudios Históricos, que se encargaban de la enseñanza del idioma en universidades extranjeras y de su preservación entre las comunidades sefarditas. El resultado fue un aumento considerable del número de lectorados, hasta alcanzar la treintena, que se repartían como sigue: siete en Alemania; tres en Italia, Francia y Gran Bretaña, dos en Checoslovaquia y Suecia, uno en Argelia, Dinamarca, Egipto, Polonia, Holanda y Japón, y cinco en los Balcanes (dos en Rumania y Yugoslavia, y uno en Bulgaria). Esa labor se acompañaba con la subvención a las cátedras de Lengua y Literatura españolas existentes en las Universidades

Sobre los antecedentes de la Junta de Relaciones Culturales, vid. NiÑo, A., "L'expansion culturelle espagnole en Amérique hispanique (1898-1936)", Relations internationales, 50 1987), págs., 197-213, y Delgado Gómez-EsCalonilLA, L., Imperio de papel. Acción cultural y política exterior durante el primer franquismo, Madrid, CSIC, 1992, págs. 9-33. 
de Utrech, Amsterdam y Poitiers, y de Historia de España del Instituto de Estudios Hispánicos de la Sorbona. Apoyo económico que se extendia también a otros centros científicos y universitarios extranjeros dedicados al estudio y promoción de la cultura española, que se habían fundado con la intervención de la Junta para Ampliación de Estudios o de la Junta de Relaciones Culturales, como eran el Instituto de las Españas de Nueva York, el Seminario de Estudios Románicos de la Universidad de Berlin, el Instituto Hispano Alemán de Colonia, el Instituto de Estudios Hispánicos de la Universidad de Bruselas y el Departamento de Estudios Hispánicos de la Universidad de Londres. Además, la Junta prestaba su concurso financiero a otra serie de entidades culturales y sociales comprometidas en la divulgación de la cultura española: el Instituto Español e Iberoamericano de Praga, la Sociedad Dano-Española, la Sociedad Hispano-Sueca, la Asociación Hispano-Noruega, la Sociedad de Amigos de España de Zurich, el Centro Español de Sofía, la Liga Hispano Helénica y el Colegio San Javier de Bombay.

El tercero de los ejes de acción prioritarios era el interés por la intensificación de los vínculos con las repúblicas hispanoamericanas, para recuperar la influencia española en el seno de la colectividad hispana. Durante el periodo republicano se elaboró un plan de acción cultural en la región, dotado con un crédito extraordinario de un millón de pesetas, que generó un fuerte debate en el seno de la Junta de Relaciones Culturales sobre su orientación y contenidos. A la postre, sólo llegaron a materializarse una parte de las medidas planificadas. Las más destacadas fueron la recopilación y envío de seis bibliotecas de cultura superior - a Argentina, Brasil, Chile, Colombia, Costa Rica y Perú, más otra que se mandó a Filipinasy once bibliotecas populares - a Bolivia, Santo Domingo, México, Cuba, El Salvador, Guatemala, Ecuador, Uruguay, Panamá, Paraguay y Venezuela-, junto a la creación de la Sección de Estudios Hispanoamericanos en el Centro de Estudios Históricos. La Junta continuó subvencionando al Instituto de Filología de Buenos Aires, sufragó también las cátedras de Literatura española de la Universidad de Panamá y de Ciencias HistóricoGeográficas de la Universidad de Bogotá, y mantuvo su colaboración con el Instituto Hispano-Mejicano de Intercambio Universitario. Otras iniciativas, como la fundación de Institutos en Buenos Aires y Río de Janeiro, se quedaron en proyectos.

Ese triple frente de actuación no agotaba, sin embargo, la obra desarrollada por la Junta de Relaciones Culturales. A su cargo estuvieron los centros españoles de alta cultura en el extranjero: la Academia de Bellas Artes de Roma, colocada bajo su tutela desde 1932, y el Colegio de España en la Ciudad Universitaria de París, inaugurado oficialmente en 
1935 aunque funcionaba en la práctica con anterioridad. La apertura de otro Colegio de España en Londres, que estaba prevista para el invierno de 1936-1937 y donde ya funcionaba una Casa-Residencia, quedó frustrada por el estallido de la guerra civil.

La Junta también alentó otras medidas dirigidas a la propagación de la cultura española: envío de conferenciantes al extranjero, remisión de lotes de libros a centros culturales y sociales, cooperación para la realización de exposiciones de arte y recitales musicales, y concesión de becas a estudiantes y profesores extranjeros para ampliar conocimientos o efectuar investigaciones en España; además de ocuparse de la organización de las colonias internacionales de vacaciones, modalidad de intercambio estudiantil que se llevó a cabo con Francia, Alemania y Gran Bretaña. Asimismo, recibieron ayuda presupuestaria de la Junta varios organismos españoles cuyas actividades favorecian el establecimiento de vínculos culturales con el exterior - la Universidad Internacional de Santander, la Unión Iberoamericana, el Comité Hispano-Inglés y la Asociación Universitaria de Madrid-, junto a instituciones académicas cuyo trabajo podía fortalecer el prestigio del país en el extranjero -así ocurrió con la Sociedad de Física y Química o la de Historia Natural, el Centro de Estudios Históricos, el Instituto Maragall de Barcelona, la Asociación de Estudios Médico-Biológicos Iberoamericanos, la Sociedad Geográfica, la Asociación Española de Derecho Internacional y la Federación de Asociaciones de Estudios Internacionales-.

Para completar este sintético balance de la actuación de la Junta resta por señalar que fue durante el período republicano cuando comenzaron a nombrarse Agregados culturales en el exterior. Representantes de estas características ejercian su labor en Francia, Estados Unidos y Argentina. En todos los casos se trataba de profesores que simultaneaban su trabajo académico en centros del país respectivo con sus responsabilidades de índole diplomática: Aurelio Viñas, Director adjunto del Instituto de Estudios Hispánicos de la Sorbona; Federico de Onís, profesor de la Universidad de Columbia-Instituto de las Españas, y Amado Alonso, Director del Instituto Español de Filología en la Universidad de Buenos Aires?

\footnotetext{
La información recogida procede de los expedientes del Archivo del Ministerio de Asuntos Exteriores (AMAE), R-727/18 y 19, R-1.729/43 y 45, R-2.460/69 y R-2.496/14. El proceso que rodeó el establecimiento de clases españolas en escuelas de Francia y Argelia en DELGADO, L. y Niño, A., “Emigración, enseñanza y nacionalidad en las relaciones hispano-francesas", Historia Contemporánea, 10 (1993), págs. 51-78. Los proyectos de acción cultural entre las comunidades sefarditas en Marouina, A. y OsPINA, G.I., España y los judios en el siglo XX. La acción exterior,
} 
A esa labor de expansión cultural también continuó prestando su aportación la Junta para Ampliación de Estudios. Esta institución tenía sin duda una trayectoria más consolidada que la de Relaciones Culturales, e incluso en el momento fundacional de ésta última durante la dictadura de Primo de Rivera puede que existiese un cierto propósito de restar competencias a aquélla ${ }^{3}$. En cualquier caso, en los años treinta esa posible rivalidad habia quedado enjugada por la presencia, a veces común en ambas, de intelectuales y científicos de ascendiente institucionista. La Junta para Ampliación de Estudios procuró a partir de entonces complementar sus actividades con la de Relaciones Culturales que, como ya se ha apuntado, favoreció económicamente a los centros de aquélla con mayor proyección internacional.

La actuación de la Junta para Ampliación de Estudios se dirigió pues, como ya venia haciendo desde tiempo atrás, a la concesión de pensiones para realizar estudios en el extranjero, cuyo número se incrementó en aquel periodo manteniéndose la preferencia por las instituciones culturales de Alemania y Francia; al intercambio científico con el exterior de los centros que estaban bajo su tutela; a la invitación a destacadas personalidades extranjeras para que intervinieran en la tribuna de la Residencia de Estudiantes; a la realización de cursos para extranjeros en el Centro de Estudios Históricos; a la organización de los cursos que anualmente impartían profesores españoles en varios países América Latina, con el concurso de las Instituciones Culturales españolas allí establecidas, y a la colaboración con el Instituto de Cooperación Intelectual de la Sociedad de Naciones ${ }^{4}$.

\footnotetext{
Madrid, Espasa-Calpe, 1987, págs. 89-112. Más datos sobre la labor de la Junta de Relaciones Culturares durante la II República en Degado Gómez-Escalonilla, L., Imperio de papel..., págs. 3447 y 56-70; Niño Rodriguez, A., "La Segunda República y la expansión cultural en Hispanoamérica", Hispania, LII, 181 (1992), págs. 629-653, y TABANERA, N., "Institucionalización y fracaso del proyecto republicano (1931-1939)", en PEREz HERRERo, P. y TABANeRA, N. (coords.), España/América Latina: un siglo de políticas culturales, Madrid, AIETI/Síntesis-OEI, 1993, págs. 49-90.

Castillejo, J., Guerra de ideas en España, Madrid, Biblioteca de la Revista de Occidente, 1976, pág. 118.

4 Sobre la actuación de la Junta para Ampliación de Estudios en el periodo republicano, vid. Laporta, F.J., Ruiz Miguel, A., Zapatero, V. y Solana, J., "Los origenes culturales de la Junta para Ampliación de Estudios (2a parte)" Arbor, 499-500 (1987), págs. 92-110; HUERTAS VÁzOUEz, E., La politica cultural de la Segunda República española, Madrid, Ministerio de Cultura, 1988, págs. 171-181, y los datos recogidos sin esa sistematización cronológica en los libros de Gamero Merino, C., Un modelo europeo de renovación pedagógica: José Castillejo, Madrid, CSIC-Instituto de Estudios Manchegos, 1988; Sánchez Ron, J. M. (coord.), 1907-1987. La Junta para Ampliación de Estudios e Investigaciones Cientificas 80 años después. Madrid, CSIC, 1988, 2 vols., y Formentin lbánez, J. y VillegGas SANz, M.J., Relaciones culturales entre España y América: la Junta para ampliación de Estudios (1907-1936), Madrid, Mapfre, 1992.
} 
Asi pues, a la altura de 1936 podía ya afirmarse que existía una política cultural exterior por parte del Estado español. Una política cultural elaborada básicamente por los intelectuales reformistas de procedencia institucionista, que habían adquirido el protagonismo en la Junta de Relaciones Culturales desde la instauración de la II República, y que dieron a través de ésta un nuevo impulso a la actividad desplegada previamente por la Junta para Ampliación de Estudios. El resultado de ese protagonismo había sido, en última instancia, la elaboración y puesta en marcha de un programa de acción definido que había logrado extender sensiblemente el radio de la acción cultural española en el extranjero, y ello a pesar de disponer de recursos económicos insuficientes para una obra de esa magnitud.

La España de mediados de los años treinta parecía haber logrado reducir la distancia que la separaba en el plano cultural de las naciones más avanzadas de Europa. No puede afirmarse que se encontrase al nivel de Francia, Alemania o Gran Bretaña. Pero sí que el programa de modernización del país a través de la ciencia y la cultura, la europeización del mundo intelectual español, habian avanzado considerablemente desde principios de siglo. Ya no se trataba sólo de que ese desnivel no existiese entre las cimas de la cultura española y sus homólogos europeos, como era el caso de la generación del 98. Ahora un nutrido sector de los investigadores, profesores, literatos 0 artistas españoles se sentían integrantes de pleno derecho de la comunidad cultural y científica internacional ${ }^{5}$.

¿Cómo era posible que precisamente entonces, cuando parecía que el país recorría la senda correcta según la famosa receta de la solución europea de España por la vía de la ciencia y la cultura, se desencadenase un fenómeno tan terrible como fue la guerra civil? ¿Cómo era posible que ello ocurriera sin que esa minoría dirigente, esa aristocracia destinada a organizar a la nación en palabras de Ortega y Gasset, pudiera impedirlo? ¿Es qué en la República de los intelectuales tenían tan poca influencia los intelectuales? Desde luego se ha propagado a veces una

5 Análisis globales sobre el sentido y alcance de esa europeización en MARICHAL, J., "La europeización de España (1898-1936)", Sistema, 86-87 (1988), págs. 53-60; VILLACorTA, F., "Les espagnols et le défi européen au XXe siècle", en GiRAult, R. (dir.), Les Europe des européens, Paris, Publications de la Sorbonne, 1993, págs. 27-41, y Niño Rodriguez, A., "La europeización a través de la política científica y cultural», en AuBERT, P. (coord.), España y Europa -en prensa- Para una visión más amplia del proceso de renovación cultural que se produjo en España durante el primer tercio del siglo, además de la obra ya clásica de MAINER, J.C., La Edad de Plata (19021939). Ensayo de interpretación de un proceso cultural, Madrid, Cátedra, 1974, vid. la reciente aportación colectiva de Garcia Delgado, J.L. (ed.), Los origenes culturales de la // República, Madrid, Siglo XXI, 1993 
imagen distorsionada de la importancia del mundo intelectual en los destinos políticos de la II República. También es verdad que por parte de ese mundo intelectual, o para ser más precisos de quienes en su seno se mostraban partidarios de una opción reformista del futuro del país, se había exagerado seguramente la capacidad regeneradora de la cultura. En el fondo era una forma lógica, consciente o inconsciente, de demandar un mayor protagonismo social ¿Existió además un error de esos intelectuales, que se retrajeron de la acción política cuando ésta no se ajustó a sus expectativas, y que favoreció que el clima de radicalización y discordia impulsado por fracciones reducidas del país terminase arrastrando al conjunto de la sociedad? ¿Faltó confianza en España y conciencia de los logros alcanzados, faltó capacidad para asimilar objetivamente el proceso histórico y edificar un proyecto de futuro más sólido? Quizás esas apreciaciones, a pesar de su indudable atractivo, también adolezcan hasta cierto punto de un talante idealista similar al que impregnaba la visión de los intelectuales sobre la realidad española de los años treinta ${ }^{6}$.

Lo cierto es que la agudización de las tensiones sociales y económicas, los enfrentamientos políticos que llevaron aparejadas, acabaron por relegar las pretensiones de regeneración por medio de la cultura tan caras a esos intelectuales reformistas. La guerra civil supuso una tremenda convulsión que socavó los esfuerzos emprendidos en diferentes ámbitos. Uno de ellos fue, obviamente, el proceso de apertura cultural hacia el exterior, truncando la prometedora trayectoria de la Junta para Ampliación de Estudios y la Junta de Relaciones Culturales.

\section{LA FRACTURA DE LA GUERRA CIVIL}

La infraestructura de personal e instalaciones dedicadas a la expansión cultural en el extranjero quedó seriamente desarticulada en el curso de la guerra civil. Aún más, los presupuestos que antes se dedicaban a estas atenciones quedaron en la práctica en suspenso, aunque formalmente fueran renovados, para dejar paso a las necesidades más apremiantes del gasto bélico.

6 La interpretación sobre el error de los intelectuales durante la II República y su falta de confianza en un proyecto histórico está tomada de MARías, J., "España ante la Historia y ante sí misma (1898-1936)", en La Edad de Plata de la cultura española (1898-1936). Identidad. Pensamiento y vida. Hispanidad, vol . XXXIX de la Historia de España de Menéndez Pidal, Madrid, Espasa-Calpe, 1993, págs. 55-128. 
En la zona republicana, las anteriores atribuciones de la Junta de Relaciones Culturales y de la Junta para Ampliación de Estudios quedaron diluidas en el Ministerio de Instrucción Pública, que concedió teóricamente el protagonismo de la propaganda cultural en el extranjero a la Casa de la Cultura, creada en Valencia en 1937. A ella se incorporaron una parte de los intelectuales y científicos que habian sido vocales en alguna de las dos Juntas. Otra parte recibió destinos oficiales en el extranjero o, más a menudo, optaron por un exilio voluntario al no sentirse identificados realmente con ninguno de los dos bandos en conflicto, al pasar a integrarse en esa Tercera España para la cual la guerra era sinónimo de fracaso, venciera quien venciese. Otra parte, en fin, menor que las anteriores, expresó su simpatía hacia el bando rebelde.

La fractura se reprodujo en el resto del personal que se ocupaba de estas funciones. En ocasiones la toma de posición ante los bandos en conflicto se produjo de forma voluntaria, otras veces optaron por seguir la corriente mayoritaria del lugar donde se encontraban, como les ocurrió a tantos otros españoles. Puesto que la sublevación militar estalló durante las vacaciones estivales, la variedad de las situaciones fue considerable. De cualquier forma, pueden extraerse dos consideraciones globales. La primera que tuvieron que definirse por una u otra causa si querían mantener sus puestos, ya que en fecha temprana recibieron la orden de presentarse ante las respectivas autoridades para demostrar su adhesión. La segunda que la mayoria de los maestros, profesores y lectores destinados en el extranjero se colocaron del lado del gobierno legítimo, mientras que los diplomáticos que también se encargaban de estas cuestiones en la Sección de Relaciones Culturales del Ministerio de Estado se decantaron unánimemente por la causa rebelde. Los efectos de todo ello sobre la acción cultural fueron evidentes, con la consiguiente merma en la capacidad de actuación de ambos bandos.

A esa fragmentación habría que agregarle la que tuvo lugar como consecuencia de la propia división acaecida en el panorama internacional, según la actitud que tomaron los distintos países hacia cada uno de los beligerantes. En conjunto, puesto que la mayor parte de los paises no otorgaron su reconocimiento diplomático al bando rebelde hasta poco antes de concluir el conflicto, el control sobre las actividades culturales que se desarrollaban en los mismos quedó en manos republicanas, aunque existiese una diversidad de matices que iban desde la total solidaridad con el gobierno legítimo hasta una abierta tolerancia hacia las iniciativas de sus antagonistas. En cambio, en los países que apoyaron a los insurrectos - Alemania, Italia y Portugal-, los servicios culturales pasaron a estar bajo la autoridad de los seguidores franquistas. 
La guerra de España se convirtió en un fenómeno político, social y cultural que movilizó a la opinión pública internacional de la época. Desde luego tal situación no fue consecuencia de los recursos puestos en juego por los contendientes para incrementar sus potenciales ayudas exteriores. Fue un fenómeno inducido por la propia polarización social e ideológica del momento y también, en buena medida, por la implicación de los intelectuales en ese proceso, que se tradujo en una activa toma de posición ante lo que se dirimía en el conflicto español. El mundo cultural europeo y americano expresó una solidaridad mayoritaria con la causa de la República, mientras que el bando franquista hubo de conformarse con la afinidad de sectores conservadores, de filiación a menudo católica o fascista ?. Aquí sólo interesa señalar un efecto añadido de esa situación: las iniciativas culturales desplegadas por los contendientes en su acción exterior estuvieron a menudo ligadas a sus repercusiones propagandísticas, al eco que eran susceptibles de encontrar para dar argumentos a los amigos o contrarrestar la actuación de los enemigos.

En el caso franquista más en concreto, al que se restringirá este trabajo en razón de su continuidad histórica ulterior, esa asociación entre cultura y propaganda resultó evidente. También lo fue la estrecha supeditación de la acción cultural a la política exterior, algo que ya no se modificaría en lo sucesivo.

La debilidad del respaldo intelectual que tuvieron los sublevados en el plano internacional se unió a las críticas sobre el desprecio por la cultura que se vertían sobre los responsables de este bando. Para reaccionar ante esa imagen negativa, los intelectuales comprometidos con el mismo recurrieron al envío de misiones propagandísticas al extranjero que divulgaran los móviles del Alzamiento. También se promocionaron los viajes a España de periodistas, escritores e intelectuales extranjeros simpatizantes con su causa, al objeto de que difundiesen más tarde una visión favorable de la zona franquista y de los motivos de su lucha, especialmente en países como Francia, Gran Bretaña, los Estados Unidos y algunas repúblicas latinoamericanas. Poco a poco esas actuaciones, fruto de iniciativas descoordinadas en un principio, se intentarían ensamblar por medio de diferentes instituciones.

Una aproximación reciente sobre el tema en GARCIA QUEIPO DE LLANO, G., “LOs intelectuales europeos y la guerra civil espan̄ola", Espacio, Tiempo y Forma, Serie V, Historia Contemporánea, 5 (1992), págs. 239-256. 
Inicialmente jugó ese papel la Comisión de Cultura y Enseñanza de la Junta Técnica del Estado, aunque su intervención en la propaganda cultural hacia el exterior fuera más bien escasa. Con el nacimiento del Instituto de España se quisó dotar de una cobertura cultural al movimiento insurreccional, aglutinando en su seno a los intelectuales más prestigiosos que se encontraban en la zona nacional. La aspiración de mostrar en el escenario internacional las preocupaciones culturales de este bando tuvo su manifestación más acabada con el restablecimiento de la Junta de Relaciones Culturales, que tuvo lugar al formarse el primer gobierno del general Franco. La medida pretendia enlazar al bando franquista con el régimen primorriverista y sentar las bases para una intervención futura. De hecho, ya en el transcurso de la guerra civil se perfiló, por parte del Ministro de Educación Nacional y Vicepresidente de la mencionada Junta -Pedro Sáinz Rodríguez-, un diseño global de la política cultural de la nueva España. Ese diseño asimilaba algunas de las líneas directrices de la actuación precedente en este terreno, pero a la vez aparecía mediatizado por la conciencia del enemigo que tan intensamente se advertía en aquel intervalo.

Entre las medidas apuntadas se mantenía la atención hacia los hispanistas; se aludía a la conveniencia de que los pensionados en el extranjero continuasen siendo un vehículo para incorporar los progresos técnicos del exterior; se enfatizaban los beneficios del envio de libros y de la creación de un repertorio bibliográfico sobre la producción literaria científica y artística en lengua española, y se insistía en la atracción de estudiantes hispanoamericanos llegando a pensarse en la organización de un doctorado hispanoamericano bajo la tutela de un Colegio de las Españas. Todo ello impregnado de un fuerte contenido ideológico, que aparecía recubierto con la apelación a una revalorización de lo español característica del grupo intelectual que colaboraba en la revista Acción Española. Esa componente ideológica era aún más acusada en la pretensión de convocar un congreso de intelectuales europeos y americanos que sirviese como reacción frente a "la revolución roja y soviética", a la par que mostrase "el contenido espiritual de la guerra española" y el compromiso de los sublevados en la "lucha por la defensa de la civilización occidental". Esa convocatoria, denominada unas veces Congreso de Occidente y otras Congreso de Intelectuales Antimarxistas, suponía la réplica contrarrevolucionaria al Congreso Internacional de Escritores Antifascistas, e iba acompañado de la propuesta de crear con sede en España un centro para la lucha antibolchevique. La idea habia partido de intelectuales conservadores franceses y había sido apadrinada rápidamente por dirigentes españoles, aunque no llegaría a cristalizar 
ante las reticencias demostradas por Alemania e Italia en el transcurso de su preparación ${ }^{8}$.

De cualquier forma, la última iniciativa mencionada dejaba patente el interés de este bando por traducir sus presupuestos ideológicos a valores culturales, susceptibles de aportar una legitimación internacional a la sublevación militar. En desigual proporción esa misma actitud estaba presente en otras actividades desarrolladas en aquel periodo, entre las que cabría destacar la participación en la Exposición Internacional de Arte de Venecia; la reanudación de los cursos de verano para extranjeros en Santander; la celebración de la Exposición Internacional de Arte Sacro en Vitoria, o las gestiones de la Sección de Relaciones Culturales encaminadas a recuperar las obras del Museo del Prado que habían sido trasladadas fuera de España por el gobierno republicano.

Junto a la vinculación entre cultura y propaganda, el otro rasgo distintivo de la política cultural franquista, la subordinación a los móviles de su política exterior, pudo apreciarse claramente en la condescendencia interesada con los amigos de la primera hora - sobre todo hacia Alemania e Italia- Si bien aqui coincidian la voluntad y la necesidad, pues la actividad del emergente Estado franquista se encontraba entonces prácticamente reducida a ese núcleo de afinidad. Las dos naciones aprovecharon el incremento de esos vínculos culturales como vía complementaria para extender su influencia entre los cuadros intelectuales y profesionales del nuevo Estado.

Las conversaciones con representantes de Alemania e Italia fueron constantes desde que se emprendieron en este bando las gestiones para llegar a una organización más eficaz de su proyección cultural. Ya a mediados de 1937 se habian hecho sondeos sobre la eventual postura de ambos países de cara a la negociación de convenios de intercambio cultural. Más adelante, tras la reconstitución de la Junta de Relaciones Culturales, tanto el gobierno alemán como el italiano no perdieron ocasión de estrechar las relaciones culturales con su aliado español.

8 La exposición de objetivos del Ministro de Educación Nacional en aActa de la primera sesión de la Junta de Relaciones Culturales", 23-IV-1938. AMAE, R-1.380/25. La posición tomada por Italia y Alemania ante la convocatoria del Congreso de Intelectuales Antimarxistas en Archivio Storico Diplomatico-Ministero degli Affari Esteri (ASD-MAE), Affari Politici 1931-1945, B-51/7 y 12. Sobre el apoyo de intelectuales extranjeros a la España franquista vid. ALTED VigIL, A., Política del nuevo Estado sobre el patrimonio cultural y la educación durante la guerra civil española, Madrid, Ministerio de Cultura, 1984, págs. 131-143, y Tusell, J. y GaAcia QueIPo de Llano, G., El catolicismo mundial y la guerra de España, Madrid, Biblioteca de Autores Cristianos, 1993. 
Alemania habia desarrollado una activa política cultural en España desde el final de la I Guerra Mundial, dirigida a mantener la germanidad de sus colonias de emigrantes, incrementar sus centros escolares y promocionar los contactos científicos. Antes de la guerra civil ya contaba con una implantación docente considerable, aún sin llegar al nivel de su rival francesa, y disponía de dos centros culturales oficiales -el Centro de Estudios alemanes y de Intercambio en Barcelona, y el Centro de Intercambio Intelectual germano-español en Madrid- y de una prestigiosa institución privada - el Centro de Investigaciones de la Sociedad Görres-, fundados todos ellos en la década de los años veinte ${ }^{9}$. Esos lazos trataron de mantenerse y estimularse, en la medida que lo permitían las circunstancias bélicas, mediante el intercambio de becarios, la dotación de lectorados en Universidades alemanas, o las invitaciones a profesores y estudiantes para que asistieran a congresos celebrados en Alemania o visitaran algunas ciudades del país. Más importante fue sin duda la firma de un "Convenio sobre la colaboración espiritual y cultural entre España y Alemania", suscrito en enero de 1939, que regularía los distintos planos de las relaciones culturales bilaterales. El convenio, sin embargo, no llegó a ratificarse. Lo impidió la oposición que ejercieron los medios eclesiásticos españoles y la Santa Sede, que veían en él un peligro potencial de hegemonía cultural y penetración ideológica del nazismo alemán sobre la católica España ${ }^{10}$. Pese a esas reticencias, las relaciones culturales hispano-germanas se intensificarían en los años siguientes, y el alemán sería una de las lenguas extranjeras favorecidas por los programas educativos oficiales, como ya había puesto de relieve la ley de reforma de la enseñanza media.

La presencia cultural italiana en España había comenzado a tener cierta entidad a partir de los años treinta, con el establecimiento de un Centro de Intercambio Cultural en Madrid destinado a mejorar la imagen del régimen fascista entre la opinión pública española y, en consecuencia, muy ligado a móviles propagandísticos. Si en el caso alemán el prestigio de su cultura y sus avances científicos y técnicos actuaban como los principales elementos impulsores de su expansión cultural, en el italiano ese papel lo ocuparía la mayor receptividad que encontraban su modelo político y sus

\footnotetext{
9 Poppinghaus, W.: “ ¿Intercambio cultural, protección cultural o imperialismo cultural? Aspectos de las relaciones culturales germano-españolas entre 1918 y 1932 ", en BERNECKER, W. L. (ed.), España y Alemania en la Edad contemporánea, Frankfurt am Main, Vervuet Verlag, 1992, págs. 89-118.

10 El contenido del Convenio cultural y un análisis de las presiones que impidieron su ratificación en MAROUINA BARRIO, A.: “La Iglesia española y los planes culturales alemanes para España», Razón y Fe, 975 (1979), págs. 354-370.
} 
presupuestos ideológicos entre cuadros dirigentes del bando franquista, cuestión que también tenía sus antecedentes en el periodo anterior ". Esa sintonia, se traducía en actividades similares a las que desplegaba el régimen alemán: intercambio de becarios, dotación de lectorados, invitaciones a profesores, o estímulo del italiano en los planes de estudio españoles. Pero además llevaba a concebir empresas más ambiciosas, como el intento de refundación de la filial española de los Comités de Acción para la Universalidad de Roma, grupos de apoyo de intelectuales extranjeros al fascismo italiano; o el propósito de dar una impronta fascista a la futura estructura cultural de la nueva España, empezando por la reforma de la escuela para la cual el Ministro de Educación español había solicitado asesoramiento documental a las autoridades italianas, y que poco después se acompañaría de la invitación a doscientos maestros españoles para que realizasen un curso en Roma sobre el ordenamiento escolar fascista ${ }^{12}$. Así pues, si para Alemania el apoyo a la España franquista permitía consolidar su anterior pujanza cultural, para Italia supuso alcanzar de forma acelerada un lugar preferente que de otra forma habría tardado mucho más en conseguir.

El escaso margen de actuación motivado por el restrictivo número de países que mantenian relaciones normales con el bando rebelde, la carencia de recursos económicos y las dificultades organizativas ocasionadas por la guerra, fueron factores que lastraron sin duda la política cultural exterior del emergente Estado franquista ${ }^{13}$. A ello habría que agregar a su vez las desavenencias ministeriales que se plantearon entre Asuntos Exteriores y Educación Nacional, con motivo de la delimitación de las respectivas competencias en materia de expansión cultural. Disputa a la que concurrian, de un lado, el protagonismo que pretendian ejercer Saínz

1 Vid. Saz Campos, 1., Mussolini contra la I/ República. Hostilidad, conspiraciones, intervención (1931-1936), Valencia, Eds. Alfons el Magnànim, 1986, págs. 85-94 y 124-138, y "Tres acotaciones a propósito de los orígenes, desarrollo y crisis del fascismo español", Revista de Estudios Políticos, 50 (1986), págs. 179-211; Selva RoCA de Togores, E., "Giménez Caballero en los origenes ideológicos del fascismo español". Estudis a Historia Contemporània del Pais Valencià, 9 (1991), págs. 183-213; GonzÁlez CALLEJA, E., “Los intelectuales filofascistas y la "defensa de Occidente" (Un ejemplo de la «crisis de la conciencia europea" en Italia, Francia y España durante el periodo de entreguerras)", Revista de Estudios Politicos, 81 (1993), págs. 129-174, y PENA SANChez, V., Intelectuales y fascismo. La cultura italiana del ventennio fascista y su repercusión en España, Granada, Eds. Adhara, 1993.

12 ASD-MAE, Affari Politici 1931-1945, B-34/3 y B-51/12.

13 Tales circunstancias se ponian de relieve en un informe que hacia balance de la labor en este ámbito. "Resumen de las actividades de la Sección de Relaciones Culturales durante el primer año de Gobierno Nacional", sin fecha (presumiblemente de los primeros meses de 1939). AMAE, A 1380/25. 
Rodríguez y su equipo de colaboradores, y del otro, la perseverancia del aparato diplomático en su afán por ejercer el control sobre esta dimensión. La ausencia de acuerdo motivó la paralización de proyectos tan importantes como el nombramiento de Agregados culturales en el extranjero, la elaboración de un nuevo reglamento de la Junta de Relaciones Culturales o su reforma para hacerla más operativa. El relegamiento de la citada Junta, poco antes de acabar el conflicto, fue el resultado final de esa falta de consenso interministerial.

Pero todo lo anterior respondía, en definitiva, a una causa más profunda: la escasa relevancia que se atribuía a la aportación de esa propaganda cultural en el esfuerzo bélico. De hecho, para los dirigentes de la sublevación militar la prioridad absoluta era vencer, aunque no llegara ni mucho menos a convencerse de la justicia de su causa. Por lo tanto, la acción cultural tuvo en todo momento un papel bastante secundario en aquella coyuntura ${ }^{14}$.

\section{REVISIONISMO INTERNACIONAL Y EXPANSION CULTURAL}

Después de la guerra civil se imponía la tarea de reconstrucción de la red cultural en el extranjero. Sin embargo, el presupuesto concedido en 1939 para esta materia fue muy reducido. La Sección de Relaciones Culturales del Ministerio de Asuntos Exteriores hubo de conformarse por el momento con restablecer parcialmente algunos de los servicios existentes con anterioridad al 18 de julio de $1936{ }^{15}$. A ese proceso se superpondría la evolución del conflicto que se desencadenó en Europa.

El curso de la guerra mundial hizo pasar a los dirigentes españoles de la expectación preocupada a la euforia poco disimulada. El avance victorioso de Alemania y la posterior beligerancia italiana se interpretaban como una continuación del combate librado en España, y puesto que el régimen franquista había estado en la vanguardia de esa lucha estaba claro que también saldría beneficiado con el cambio internacional que se avecinaba. En los círculos intelectuales del nuevo Estado, con especial incidencia en

\footnotetext{
14 Una descripción más pormenorizada de la política cultural exterior del bando franquista durante la guerra civil en ALted VigIL, A., Politica del nuevo Estado..., págs. 111-129 y 231-248, y Delgado Gómez-Escalonilla, L., Imperio de papel..., págs. 71-115.

15 "Sucinta exposición sobre la Obra Pía y Relaciones Culturales", 19-X-1939. AMAE, R $2.467 / 64$.
} 
medios falangistas, se especuló sin recato con la posibilidad del alineamiento militar con las potencias del Eje. Tal alineamiento no se produjo más que tangencialmente, caso de la División Azul en el frente ruso, pero lo que desde luego sí tuvo lugar fue un claro y amplio alineamiento ideológico y propagandístico.

La vocación de Imperio fue un argumento empleado por los círculos intelectuales, aunque no sólo por éstos, para justificar una táctica de expectativa y propaganda, de camaradería fascista a la espera de que llegase la hora de la verdad. Desde la Falange nunca se habia ocultado una voluntad revisionista dirigida a recobrar un papel protagonista para España en el orden internacional, una disposición que ya habia dejado testimonios en el curso de la guerra civil y que incrementaría su audiencia al socaire de los triunfos del Eje ${ }^{16}$. No faltaron interpretaciones donde se defendía abiertamente la conveniencia de acometer empresas exteriores, especialmente en el terreno colonial, como medio para cimentar la unidad nacional. Pero, ante la incapacidad del régimen español para materializar militarmente su compromiso con el Eje, la respuesta de esos intelectuales fue traducir a términos culturales su compromiso beligerante. Desde las páginas de la Revista de Estudios Políticos y de Escorial varios artículos dejaban claro que los intelectuales no podían reproducir la postura claudicante o inhibida de tiempos pasados; que había que tomar partido para poder reclamar un puesto en el escenario internacional; que el campo de los enemigos de la recuperación exterior española - comunismo, capitalismo, democracia liberal, Francia e Inglaterra- señalaba la dirección a tomar y, en definitiva, que la cultura militante española debía alinearse con la Europa del Nuevo Orden, sustentada en los pilares de la Antigüedad clásica, el Cristianismo y la Germanidad " ${ }^{17}$.

is Vid. como manifestaciones representativas de esa tendencia, XIMÉNEZ DE SANDOVAL, F., "Esquema de una política exterior nacionalsindicalista", Fe (Zaragoza), 4 (1937), págs. 187-194; Urrutia, F. de, La Falange Exterior, Santander, Delegación Nacional del Servicio Exterior, 1938; Tovar, A., El imperio de España, Madrid, Afrodisio Aguado, 1941; Areilza, J.M. y CASTIELLA, F.M., Reivindicaciones de España, Madrid, Instituto de Estudios Políticos, 1941; Cordero TorRES, J.M., La misión africana de Espan̄a, Madrid, Eds. de la Vicesecretaria de Educación Popular, 1941, y Aspectos de la misión universal de España, Madrid, Eds. de la Vicesecretaría de Educación Popular, 1942, o la más tardía y ya a contracorriente de Montero Diaz, S., Idea del imperio. Politica Nacional y Política Internacional, Madrid, Escuela de Forrnación y Capacitación de la Vieja Guardia, 1943. También rememoran esa actitud los testimonios de algunos de los protagonistas de aquella época, Serrano Suñer, R., Entre el silencio y la propaganda, la Historia como fue: Memorias, Barcelona, Planeta, 1977; Lain Entralgo, P., Descargo de conciencia (1930-1960), Barcelona, Barral, 1976, y RidRuEJo, D., Casi unas memorias, Barcelona, Planeta, 1977.

17 Gancia Valdecasas, A., "Política exterior", y "Relaciones culturales y política exterior", Revista de Estudios Políticos, 1 (1940), págs. 7-16, y 3 (1941), págs. 517-529; "Ante la guerra", "Nosotros ante la guerra", y "La cultura en el Nuevo Orden europeo", Escorial, 3 (1941), págs. 159 -164, 8 (1941), págs. 325-331, y 15 (1942), págs. 5-10, respectivamente. 
Con todo, la tónica imperante desde la óptica intelectual fue el recurso a las evocaciones retrospectivas, a la recreación de la época en que España había sido un Imperio, con capacidad para intervenir en la articulación política del continente europeo y para ejercer sobre el mismo su influencia cultural de signo católico ${ }^{18}$. ¿Qué otra cosa podía aportar España a la edificación de la Europa del Nuevo Orden? Su pasado imperial, su espíritu católico y, por supuesto, algo que aparecía menos en las declaraciones públicas, pero que tenía mucha más importancia que lo anterior en sus relaciones con los nuevos amos de Europa: sus materias primas ${ }^{19}$. De una u otra forma, ese discurso reivindicativo vino a paliar la frustración que supuso la incapacidad para consumar la tentación española ${ }^{20}$.

La actitud beligerante de esos intelectuales comprometidos no tuvo, por otra parte, un reflejo directo sobre la política cultural, sin que ello signifique que esta dimensión de la política exterior quedase al margen de la oleada de revisionismo internacional que se extendió entre los dirigentes españoles en los primeros años de la guerra mundial ${ }^{21}$. Esas formulaciones tuvieron una relativa traslación a aspectos puntuales de las relaciones culturales, pero nunca aparecieron ensambladas en un proyecto homogéneo, ni llegarian a materializarse más que de forma fragmentaria. Es más, el protagonismo de la política cultural no estuvo en manos de los partidarios de una mayor implicación en los asuntos internacionales que se dirimían en aquella coyuntura, salvo en algunas materias y durante un tiempo limitado. Los medios diplomáticos fueron quienes marcaron comúnmente la pauta de la labor a desarrollar, a través de la Sección de Relaciones Culturales, y sus principales colaboradores ajenos a la carrera serían los miembros del Consejo Superior de Investigaciones Científicas, que no en vano era el heredero de

18 Ejemplos de ambas interpretaciones en Beneyto Perez, J., España y el problema de Europa. Contribución a la historia de la idea de Imperio, Madrid, Editora Nacional, 1942, y PINzón Toscano, A., Defensa española de la cultura europea, Madrid. Eds. de la Vicesecretaria de Educación Popular, 1942.

19 Vid. Garcia Pérez, R., Franquismo y Tercer Reich. Las relaciones económicas hispano-alemanas durante la Segunda Guerra Mundial, Madrid, Centro de Estudios Constitucionales, 1994.

20 Analisis parciales sobre el tema en SOUTHWORTH, H.R., Antifalange. Estudio crítico de "Falange en la guerra de España" de M. Garcia Venero, París, Ruedo Ibérico, 1967, págs. 39-61; Las fuentes ideológicas de un régimen (España 1939-1945). Zaragoza, Pórtico, 1978; Lazo Diaz, A., "El fascismo europeo en las publicaciones católicas de postguerra", Sistema, 77 (1987), págs. 37-76, y GaRCIA PEREZ, R., "La idea de la "Nueva Europa" en el pensamiento nacionalista español de la inmediata postguerra 1939-1944", Revista del Centro de Estudios Constitucionales, 5 (1990), págs. 203-240.

21 A título casi de excepción puede mencionarse la obra de IBANEZ DE İBERO, C., La personalidad internacional de España, San Sebastián, Ed. Española, 1940, que incluia un capitulo dedicado a la "Expansión cultural»;, págs. 234-264. 
las instalaciones y cometidos de la Junta para Ampliación de Estudios. Ello no obsta para que se produjera una marcada aproximación hacia Alemania e Italia, que también tuvo un cierto correlato con Portugal, aunque de menor intensidad. Ni para que las relaciones culturales con Francia atravesaran fases de tensión provocadas por la actitud reivindicativa española, que obligaron a las autoridades galas a hacer concesiones sustentadas sobre el principio de la reciprocidad. Pero los diplomáticos siempre fueron refractarios a permitir la interferencia de otros sectores del régimen en lo que consideraban sus funciones privativas. Así lo mostró la experiencia de las relaciones culturales con América Latina, donde se concentraron temporalmente las expectativas revisionistas de los círculos intelectuales falangistas.

Por paradójico que parezca, los ejes de intervención de la política cultural franquista se atuvieron en muchas facetas a la dinámica establecida por la II República. Así lo puso de relieve la actuación de la Sección de Relaciones Culturales a partir de 1940, una vez que dispuso de un presupuesto que le permitió cierta capacidad de maniobra ${ }^{22}$.

En su balance de resultados de ese año destacaba la puesta en marcha de los centros docentes en el extranjero, con el restablecimiento del Instituto Español de Lisboa y de las escuelas y clases españolas en Andorra, Portugal, Francia y el norte de Africa. A esos centros se añadían además las subvenciones de la Sección a varias escuelas religiosas en Andorra y a las escuelas de misioneros españoles en Gran Bretaña y en la India inglesa, éstas últimas de nueva creación y que respondían a un plan de conjunto realizado por el Instituto Ibérico Oriental que se estaba organizando en Barcelona. En su conjunto totalizaban una cifra de treinta y seis docentes entre profesores de instituto, maestros y religiosos, que recibian fondos o cobraban su sueldo con cargo al presupuesto de la citada Sección. Entre sus cometidos figuraba, en claro paralelismo con la época republicana, la atención a las bibliotecas enviadas por la Sección y la constitución de Patronatos para el fomento de la cultura española.

22 Los datos sobre la actuación de la Sección que figuran a continuación están tomados de "Exposición sucinta y breves comentarios acerca de la situación actual de los Establecimientos Culturales y del Personal en el extranjero dependientes de este Ministerio (Relaciones Culturales). Nota informativa (Confidencial)», 18-XI-1940, e “indice de la labor efectuada por la Sección de Relaciones Culturales y Obra Pia durante el año 1940", 16-XII-1940. AMAE, R-2.467/64. En cuanto a la dotación para relaciones culturales del Ministerio de Asuntos Exteriores fue de 2.362.000 pts. en ese año. En 1939 esa cantidad sólo habrá alcanzado las 670.283 pts., de las cuales una parte se destinó a liquidar compromisos contraidos en la guerra civil. La información que se ofrece a continuación sobre las relaciones culturales en los primeros años de la guerra mundial puede completarse en Delgado Gómez-Escalonilla, L., Imperio de papel..., págs. 173-236. 
También merecia un lugar sobresaliente entre sus actividades el nombramiento de veintiséis lectores españoles en Universidades extranjeras: seis en Italia, cinco en Francia - cuatro de ellas en la Argelia francesa-, cuatro en Alemania, dos en Suecia, Rumania y Suiza, y uno en Dinamarca, Egipto, Marruecos, Turquía y Portugal. Su distribución hacía recordar asimismo al período republicano, aunque se apreciasen algunas diferencias como eran la desaparición de las plazas que anteriormente existían en Gran Bretaña o el crecimiento de las localizadas en el norte de Africa, cuestión esta última que había estado motivada «más bien en criterios de política islámica que en razones de índole meramente cultural»». Por otro lado, estaba en proyecto incrementar aún más en el año siguiente los lectorados en Italia, Alemania y Francia. Hacia estos países, junto a Portugal, se dirigía buena parte de la política cultural de España en Europa en aquellos instantes, como ponian de relieve otras medidas tomadas entonces que tendremos ocasión de comentar más adelante.

La política cultural hacia América Latina tampoco había sido descuidada. Se trataba de una dimensión que tenía un especial interés para el Ministerio de Asuntos Exteriores. Desde la óptica del Estado franquista esta región constituía uno de sus principales móviles de afirmación exterior, retomando así una aspiración de la política exterior española que venía de tiempo atrás. Tras la conclusión del conflicto interno, y una vez que la normalización de las relaciones diplomáticas estaba en vía de consolidación, se pretendia impulsar una política más activa hacia la zona. Para ello podian aprovecharse la red de colaboraciones que se habian obtenido durante la guerra civil por parte de asociaciones de las colonias españolas, de grupos políticos y sociales latinoamericanos, y de las filiales falangistas creadas en la mayor parte de los paises. Sin embargo, era preciso hacer frente a las campañas de descalificación del régimen alentadas por sectores democráticos de las sociedades latinoamericanas, por los incipientes núcleos del exilio español que empezaban a formarse en varias repúblicas de aquel continente y, más importante aún, por la actuación de los Estados Unidos, que tomaba medidas preventivas ante la eventualidad de que la dictadura española se convirtiera en una avanzadilla de las potencias del Eje en América. Frente a las dificultades que esto ocasionaba a las organizaciones falangistas para el desarrollo de su acción propagandística y su labor de captación de los emigrantes españoles, la política cultural resultaba un medio de influencia mucho menos conflictivo para proyectar hacia América Latina los presupuestos ideológicos del régimen e intentar modificar esa imagen negativa.

La Sección de Relaciones Culturales habia estudiado ya en 1939 la posibilidad de celebrar una exposición de prensa iberoamericana, con 
motivo del 12 de octubre de 1940, que se simultanearía con la convocatoria del primer Congreso de periodistas iberoamericanos. Obviamente, tras esa reunión estaba el deseo de que sirviera para contrarrestar las tendencias anti-franquistas presentes en la opinión pública latinoamericana. Dichos actos no se realizaron finalmente, aunque la Sección intervino en la preparación de los eventos conmemorativos de la fiesta de la Hispanidad de ese año. También subvencionó a la misión pedagógica desplazada a Ecuador a solicitud del gobierno de aquel país para realizar tareas de asesoramiento; se ocupó del envio a países de la zona y a Filipinas de más de 6.000 volúmenes de autores españoles sobre temas literarios y científicos, repartiéndose "con profusión las obras referentes a nuestro Glorioso Movimiento", e incluso proyectó la creación de cátedras de hispanidad en centros de segunda enseñanza al otro lado del Atlántico. Junto a todo lo anterior, la Sección colaboró con aquellos organismos que buscaban estrechar las relaciones culturales con América Latina. Directamente ligada al propio Ministerio de Asuntos Exteriores estuvo la iniciativa de fundar la Asociación Cultural Hispano Americana, una entidad para-estatal cuya constitución estuvo asociada al objetivo de utilizar sus servicios como canal complementario de la política exterior, en analogía a su vez con el cometido que desde el aparato diplomático se pretendió asignar a la Unión Iberoamericana durante el periodo republicano. En el ámbito académico esa cooperación se tradujo sobre todo en la ayuda para difundir la labor de los centros del Consejo Superior de Investigaciones Científicas, ya estuvieran específicamente dedicados a los estudios sobre la región como era el caso del Instituto Gonzalo Fernández de Oviedo, o bien se tratara de estimular los vínculos científicos de todo tipo para recuperar los contactos perdidos a causa de la guerra civil y elaborar una Guía cultural de España, Portugal, América hispana, Brasil y Filipinas.

La relación entre la Sección y el Consejo se extendió asimismo a otras tareas, dado que a cargo de este último organismo quedaron el intercambio de profesores con el extranjero, la asistencia a congresos y conferencias internacionales, la formación de investigadores y especialistas pensionados fuera del país, la organización y mantenimiento de centros científicos en el extranjero -empezando a título de ensayo con la Escuela Española de Arqueología e Historia en Roma-, la difusión de la labor de los investigadores españoles y el intercambio de publicaciones científicas ${ }^{23}$.

23 El Jefe de la Sección de Relaciones Culturales fue nombrado en el curso de 1940 miembro del Consejo Superior Ejecutivo del citado organismo, Vicepresidente de su Junta Bibliográfica y de Intercambio Científico y vocal del Consejo Nacional de Educación. 
En suma, una réplica casi literal de los cometidos asignados antes de 1936 a la Junta para Ampliación de Estudios. La Sección prestó su contribución en todas estas materias y se ocupó, además, de la petición formulada por el Consejo para que se remitiese información sobre las instituciones encargadas de la investigación en los diferentes paises; de dar a conocer en el exterior sus diversos institutos y los trabajos que desarrollaban, y de recopilar datos sobre actividades culturales en el extranjero relacionadas con España con destino a la confección de un Anuario de Hispanismo ${ }^{24}$.

A las medidas señaladas habría que añadir el nombramiento de Agregados o Consejeros culturales en varias representaciones diplomáticas - Pedro Ara en Buenos Aires, Manuel Carrasco Reyes en Roma, Samuel Crespo en París, María de Maeztu en Santiago de Chile y Gregorio Corrochano en el Consulado General de Tánger-, cargos que tenían un carácter honorario y gratuito. Por último, apuntar que la Sección también actuó en la creación del Consejo Superior de Misiones Religiosas Españolas en el extranjero, ante el convencimiento de que los religiosos españoles deberian ser uno de los más firmes puntales de la expansión cultural y la influencia política de España a nivel internacional. Esa modalidad de intervención estaba destinada a tener una gran repercusión años después.

Lo cierto es que el régimen no aportó ni una concepción alternativa, ni mejoras sustanciales respecto a la actuación emprendida en la política

24 Sobre la participación del Consejo Superior de Investigaciones Cientificas en las relaciones culturales con el extranjero vid. la documentación recogida en AMAE, R-2.178/1-10, y las Memorias de la Secretaria General, años 1940-1941, 1942, 1943, 1944 y 1945. Madrid, CSIC, 1942-1946. Mientras que se conoce con cierto detalle la actuación de la Junta para Ampliación de Estudios, la trayectoria del Consejo Superior de Investigaciones Científicas sigue desconociéndose en buena parte. De hecho, en una reciente publicación conmemorativa de los cincuenta años de su creación se expresaban juicios contradictorios sobre su labor, vid. El CSIC: una visión retrospectiva, $n^{\circ}$ monográfico de Arbor, 529 (1990). Entre los escasos trabajos que se han ocupado de este organismo cabe destacar los de Gonzalez Blasco, P. y Giménez BlanCo, J., "La investigación en el Consejo Superior de Investigaciones Cientificas. Estudio de un grupo significativo durante el periodo 1940-1955", en GonzAlez BLASCO, P. et alii, Historia y Sociologia de la Ciencia en España, Madrid, Alianza, 1979, págs. 126-162; PASAmar AlzURIA, G., Historiografía e ideologia en la postguerra española: La ruptura de la tradición liberal, Zaragoza. Prensas Universitarias de Zaragoza, 1991, y "Oligarquías y clientelas en el mundo de la investigación científica: el Consejo Superior en la Universidad de posguerra", en CaRRERAS ARES, J.J. y RuIz CARNicer, M.A. (eds.), La Universidad española bajo el régimen de Franco (1939-1975). Zaragoza, Institución Fernando el Católico, 1991, págs. 305-339, y Lopez Garcia, S., Ciencia, tecnologia e industria. Herencia institucionales y nueva politica científica en la constitución del Patronato "Juan de la Cierva" (19391945), Documento de trabajo $n^{\circ} 9.302$, Madrid, Facultad de Ciencias Económicas y Empresariales de la Universidad Complutense. 1993. Dichos trabajos sólo cubren una mínima parte de lo que fueron las múltiples dimensiones del Consejo en la vida cultural del franquismo. 
cultural antes de la guerra civil. Tampoco parece que tales intenciones figurasen entre sus objetivos esenciales. Los medios económicos que se asignaron inicialmente a ese cometido distaron de ser suficientes para ir más allá del simple restablecimiento de una infraestructura heredada en muchos casos de la II República y, en términos reales, estuvieron por debajo de los recursos presupuestarios destinados a la política cultural en aquel periodo ${ }^{25}$. Otro problema añadido fue la carencia de personal preparado, de los cuadros humanos que engrosaron las filas de la emigración política, aunque ese vacio se intentó suplir con el envío al extranjero de profesores y lectores que habrian de actuar como prosélitos de los principios del Movimiento Nacional, tras el preceptivo proceso de depuración y selección ${ }^{26}$. Más difícil resultaba a corto plazo restablecer los vínculos que antes existían con importantes centros universitarios dedicados al estudio y promoción de la cultura española. En muchos de ellos la actitud de los profesores había sido mayoritariamente favorable a los rojos durante la guerra civil, y ahora cubrían sus plazas en esta materia con algunos de los prestigiosos profesores españoles que se habian visto obligados a tomar el camino del exilio - así había ocurrido en París, Londres, Nueva York o Bruselas-.

Además de lo apuntado previamente, es posible apreciar que la política cultural del régimen franquista se encontró a menudo, en algunas de sus líneas de acción más importantes, a remolque de sus principales interlocutores internacionales o de la evolución de la contienda mundial. Con ello venía a ponerse de manifiesto una vez más la extrema dependencia que presentaba la acción cultural respecto a las demandas de la política exterior. La disparidad de los intercambios culturales que mantuvo con los dos bandos beligerantes, tanto en su volumen como en el talante con que se desarrollaron, supone una buena muestra de ello.

Las relaciones culturales con los paises del Eje alcanzaron una notable intensidad, apreciable en intercambios de diversa indole. Para Alemania e

25 Los propios responsables de los organismos gestores de la política cultural emitieron reiterados testimonios sobre la precariedad de recursos en que se desenvolvia esa labor, siempre por supuesto dentro de los circuitos reservados de la administración. Vid., a título de ejemplo, "Sucinta exposición sobre la Obra Pia y Relaciones Culturales", 19-X-1939 (AMAE, R-2.467/64) "Memoria sobre el proyecto de presupuesto de Relaciones Culturales para 1941", 12-X11-1940 (AMAE, R-2.138/2), y "Memoria sobre las modificaciones que se proponen para el presupuesto de 1943 en los créditos de Relaciones Culturales", 2-X-1942 (AMAE, R-2.460/68).

26 Vid. "Cátedras y Lectorados de español en el extranjero", 14-II-1940. AMAE, R-2.496/14 "Instrucciones a los maestros españoles dependientes de la Sección de Relaciones Culturales del Ministerio de Asuntos Exteriores", 16-V|-1941. Boletin Oficial del Ministerio de Asuntos Exteriores, 30-VI-1941. 
Italia este canal permitía ganar adeptos entre los sectores dirigentes de la dictadura española, en el mundo de la cultura y la ciencia, de la información y en distintos cuerpos de la administración. También ofrecía un medio para realizar una propaganda encubierta de sus móviles internacionales, ya que oficialmente estaba prohibida la propaganda directa de los beligerantes. Para España suponía, sobre todo, un medio de consolidar su afinidad con los pilares básicos de la Europa fascista, de mostrar su solidaridad moral con los designios políticos de sus interlocutores totalitarios, de incrementar su paulatina integración en las estructuras del Nuevo Orden.

Tanto Alemania como Italia fundaron en los primeros años de la guerra mundial sendos Institutos de Cultura en la capital española, que recogian el testigo de los centros preexistentes pero elevados ahora de categoría y con mayores recursos. La cordialidad existente entre ambas naciones llevó en ocasiones a una coordinación mutua para obstaculizar la acción de sus adversarios, sin que ello impidiera una cierta rivalidad para lograr un puesto preeminente en el panorama cultural y político español.

Alemania favoreció una rápida regularización del intercambio de publicaciones con España, que se vió apoyada por la donación de las obras que compusieron la Exposición del Libro Alemán celebrada en 1940 en Madrid y Barcelona. El Instituto Alemán de Cultura colaboró en todo momento a esa tarea y, además, mantuvo un estrecho contacto con el Consejo Superior de Investigaciones Científicas para desarrollar las relaciones entre investigadores españoles y alemanes, y estimuló el intercambio de profesores y el envío de lectores de español, becarios y pensionados, contando para ello con la ayuda de los organismos alemanes correspondientes. En todas estas vertientes cabe afirmar que el protagonismo alemán en aquellos años estuvo muy por delante del que pudo adquirir cualquier otro país, incluida Italia. La nación mediterránea fue a la zaga de la influencia cultural alemana, si bien no bajó la guardia y procuró dar la réplica en la medida de sus posibilidades tanto en la normalización del intercambio bibliográfico, del que se encargó especialmente el Instituto para las Relaciones Culturales con el exterior, como en el resto de las facetas enunciadas. De hecho, en los primeros momentos de la organización del Consejo hubo misiones culturales tanto a Alemania como a Italia. En el primer caso a cargo de miembros del Instituto de Física, para adquirir libros y material científico; examinar las posibilidades de alojamiento de profesores españoles en Berlín; gestionar el desplazamiento a España de profesores alemanes a fin de que formasen escuela en varias disciplinas, y estudiar el funcionamiento del Laboratorio Imperial de Física y Química y de la Escuela Politécnica de Berlín. En el caso italiano esa 
misión tuvo lugar a invitación del Instituto de Alta Matemática de Roma, que expresó su deseo de recibir estudiantes españoles para ampliar su formación científica y planteó la conveniencia de organizar en Roma una institución que acogiese a los pensionados y los técnicos españoles, otorgando además dos becas para estudiantes. Tal iniciativa mereció el beneplácito del Ministerio italiano de Asuntos Exteriores que completó esa oferta con otras siete becas ofrecidas por el Instituto para las Relaciones Culturales con el exterior.

Desde luego, los gobiernos alemán e italiano, bien a través de sus centros universitarios y de investigación, bien por medio de otros organismos oficiales, se mostraron en todo momento muy receptivos en cuanto afectaba a ese intercambio cultural. Un intercambio que junto a las iniciativas aludidas cubrió asimismo otra variada gama de actividades: ampliación de la red docente alemana e italiana en España, que iria acompañada del incremento paralelo del número de lectorados de ambas nacionalidades en centros españoles y de los profesores de enseñanza secundaria dedicados a impartir los dos idiomas; visitas a Alemania e Italia de ingenieros españoles de diversos campos de especialización; invitaciones a profesores, periodistas, escritores o funcionarios españoles para asistir a congresos y reuniones internacionales; firma de acuerdos de colaboración en materia cinematográfica y jurídica; exposiciones artísticas; celebración de ciclos de música clásica y de ópera; representaciones de los coros y danzas españoles, e incluso acogida de viajes turísticos a España. A lo que hay que añadir el nombramiento de Consejeros culturales españoles en ambos países, en Italia el citado líneas atrás, y en Alemania desde finales de 1942 el diplomático Ignacio Oyarzabal, aunque desde comienzos de 1941 actuaba como representante del Consejo en Berlin. Sin descuidar, por otra parte, algunas actuaciones donde la frontera entre la cultura y la propaganda era más evanescente, como eran la donación de objetos de culto para las iglesias destruidas y las visitas de religiosos italianos y alemanes a España, vía para contrarrestar la propaganda realizada en este sentido por franceses y británicos, y de forma mucho más evidente los intercambios de delegaciones de los respectivos partidos únicos. A este respecto hay que destacar que ese tráfico partidista fue variado y fluido, incluyendo a representantes de las organizaciones juveniles, de los Institutos de Estudios Políticos, de las secciones femeninas, de los servicios de Auxilio Social, de los sindicatos universitarios, de las secciones deportivas o de los ex-combatientes.

En las relaciones culturales con las naciones del Eje el desequilibrio por parte del Estado español fue una constante, aunque sin duda cabe apreciar una disparidad algo menor por lo que respecta a Italia. En ese país 
existía una infraestructura de centros culturales españoles y, además, la afinidad con los dirigentes italianos era más acusada, de ahí que se buscase una mayor reciprocidad. Incluso llegaron a crearse un Ente italiano para la colaboración técnico-científica con España y un Comité interministerial español para el intercambio cultural con Italia, el primero a semejanza del que ya funcionaba con Alemania desde 1939 y el segundo con el propósito de que también extendiera su radio de acción al intercambio cultural con Alemania. Sin embargo, el tiempo que pasó entre la propuesta italiana para poner en marcha tal medida - diciembre de 1940 - y la respuesta afirmativa española - diciembre de 1941- ilustra suficientemente la lentitud con que reaccionaba el régimen español ante el mayor dinamismo de sus camaradas europeos. A la postre, los efectos de esos organismos fueron bastante limitados, como también lo fueron las actividades desarrolladas por los centros culturales españoles en Italia. La reforma de la Academia de Bellas Artes en Roma permaneció paralizada hasta la incorporación a finales de 1940 de su nuevo Director, Manuel Halcón, un año después de su nombramiento. Su posterior designación al frente del Consejo de la Hispanidad acabó de complicar la situación hasta mediados de 1942, fecha en que se formó una Junta para el fomento y enlace de la acción e Instituciones culturales de España en Roma. Hasta ese año no hubo pensionados españoles en aquel centro. También comenzaron a funcionar con regularidad durante ese año la Casa de Cervantes en Bolonia, cuyo Director era el Rector del Colegio de San Clemente de los Españoles que ejercía a su vez el cargo de Agregado cultural, y la Escuela Española de Arqueología e Historia en Roma, que se venía reorganizando desde tiempo atrás de acuerdo con el Consejo Superior de Investigaciones Científicas. En idéntica fecha se tomó la decisión de fundar un Instituto-Academia de Lengua y Literatura españolas en Roma. El despliegue se mostró tan ambicioso como fugaz, pues al año siguiente el territorio italiano quedó convertido en campo de batalla ${ }^{27}$.

Finalmente, dentro de ese mismo círculo de países amigos, también se acrecentó el intercambio cultural con Portugal, al objeto de afianzar la

27 La constitución de los organismos de colaboración hispano-italiana en "Nota del Ministerio de Asuntos Exteriores a la Embajada de Italia en España", 23-XII-1941, y "Costituzione dell'Ente italiano per la collaborazione tecnico-scientifica con la Spagna", 29-I-1942. ASD-MAE, Affari Politici 1931-1945, B-63/19. El prolongado proceso de interinidad que sufrió la Academia y su tardia reforma están documentados en el Archivo de la Academia Española de Bellas Artes de Roma, Comunicaciones oficiales, 1936-1946. En cuanto al despliegue organizativo que tuvo lugar a mediados de 1942 pudo estar conectado con las aspiraciones de Ramón Serrano Suñer de prepararse una retirada estratégica a la Embajada de Roma ante sus problemas en la escena politica española. Vid. Tusell, J. y Garcia Quelpo de Llano, G., Franco y Mussolini. La política española durante la segunda guerra mundial, Barcelona, Planeta, 1985, págs. 154-164. 
sintonía existente entre ambas naciones peninsulares. Desde la guerra civil el bando franquista había ido restableciendo la actividad de los centros culturales españoles alli radicados, y aunque las escuelas y el Instituto de Lisboa pasaron por serios apuros financieros, hasta el punto de pensarse en el cierre de este último, motivos de prestigio frente al país vecino terminaron decidiendo a los responsables españoles por mantener la estructura docente previa. Hubo conversaciones a instancia de delegados del Consejo Superior de Investigaciones Científicas para favorecer las relaciones culturales en diferentes materias -intercambio de profesores, estudiantes y publicaciones, reconocimiento de títulos, colaboración en cursillos y revistas, etc.-, y se proyectó asimismo la constitución de un Ente luso-español para cuestiones referentes a Ingeniería. No parece que tal iniciativa acabara cuajando en un esquema elaborado de colaboración bilateral sobre la materia. De cualquier forma si que se mantuvo un activo intercambio que, aunque no alcanzó las dimensiones de Alemania o Italia, incluyó el nombramiento de un Agregado cultural en Lisboa - Eugenio Montes, Director del Instituto Español-, la asistencia oficial de España a las fiestas conmemorativas de los Centenarios portugueses en 1940, conferencias, emisiones radiofónicas, exposiciones de pintura, conciertos musicales, y viajes de intercambio de estudiantes y profesores de ambos países, preferentemente relacionados con diversas ramas de la Ingeniería.

Mucho menos condescendiente fue la actitud de los responsables de la política cultural española hacia las principales naciones del bando aliado. Con la derrotada Francia de Vichy el resentimiento y la voluntad revisionista de los portavoces de la dictadura franquista pusieron a prueba la capacidad conciliadora gala, obligada a flexibilizar su postura ante demandas hacia las cuales con anterioridad había mostrado una tenaz intransigencia, particularmente en la aceptación de la reciprocidad en el establecimiento de escuelas españolas en su territorio metropolitano y en sus colonias del norte de Africa. Una reciprocidad que al final tuvo que aceptar formalmente, aunque la medida no llegara a consolidarse debido al cambio de signo de la guerra y, posteriormente, a la transformación política que se produjo en Francia. Esa flexibilidad francesa también le permitió conservar, no sin ocasionales sobresaltos, la considerable infraestructura cultural de que disponía en España antes de la guerra civil, con la excepción de la Casa de Velázquez cuya sede no fue reconstruida hasta tiempo después. No en vano, para la diplomacia gala, desprovista de otros medios de acción más influyentes, ese canal cultural servia para limar asperezas con los susceptibles dirigentes españoles, además de contrapesar de esta forma la creciente presencia cultural de Alemania e Italia. Así, por medio de su Embajada y de sus centros culturales en España las autoridades francesas 
realizaron importantes donativos bibliográficos y de material científico; organizaron exposiciones de arte, conferencias de profesores franceses y audiciones musicales; llevaron a cabo diversas demostraciones de confraternidad religiosa; repartieron información periódica de las publicaciones francesas a instituciones universitarias y cientificas españolas; favorecieron el intercambio de periodistas con el propósito de restar virulencia a las campañas de prensa anti-francesas, etc. Por lo que respecta a la principal institución cultural española en Francia, el Colegio de España en la Ciudad Universitaria de París, su actividad se vió muy mermada a causa de los sucesivos conflictos bélicos. Durante la guerra civil fue foco de disputa entre republicanos y franquistas a la par que sufrió graves problemas presupuestarios, más tarde, cuando se disponía a reiniciar sus tareas tras las reformas necesarias, la guerra mundial y la ocupación alemana convirtieron a la Ciudad Universitaria de Paris en un campamento militar ${ }^{28}$.

Con Gran Bretaña y los Estados Unidos esos intercambios culturales fueron mucho más limitados. Las naciones anglosajonas emplearon también la vía del intercambio bibliográfico y de las donaciones como una forma de favorecer las relaciones culturales con España. Mientras que Estados Unidos asignaba esa tarea a la Biblioteca del Congreso de Washington, en el caso de Gran Bretaña esa labor corrió a cargo del Instituto Británico en Madrid. Esta institución se fundó igualmente en los primeros años de la guerra mundial, con el objetivo de impulsar la difusión cultural británica en España e intentar paliar la creciente implantación en este ámbito de los países del Eje. Sin llegar a adoptar medidas equivalentes a las que tomaron Alemania, Italia o Francia, se concedió una particular atención a los cursos de inglés; a la organización de conferencias, recepciones, conciertos y exposiciones; a la colaboración con organismos culturales y científicos españoles, y a fomentar los contactos entre sectores religiosos de ambos países, iniciativa esta última a la que contribuyó

28 Balances de la contraofensiva cultural francesa en «Propagande française en Espagne en 1941", 25-111-1942 - Archives Diplomatiques-Ministére des Affaires Etrangères (AD-MAE), Vichy Europe 1939-1945, Espagne, vol. 254-, y en PIETRI, F., Mes années d'Espagne, 1940-1948, Paris, Librairie Plon, 1954, págs. 213-232. Sobre los antecedentes de las relaciones culturales hispano francesas vid. NiÑo, A., Cultura y diplomacia: los hispanistas franceses y España. De 1875 a 1931. Madrid, CSIC-Casa de Velázquez-SHF, 1988, y DeLAunay, J.M., 'L'Espagne, un champ ouvert. Rivalités ef illusions culturelles en péninsule ibérique (X|Xe-XXe siècles)", Relations internationales, 50 (1987), págs. 215-227, y Des Palais en Espagne. L'Ecole des hautes études hispaniques et la Casa de Veláquez au coeur des relations franco-espagnoles du XXe siècle (1898-1979), Madrid, Casa de Velázquez, 1994. El desarrollo del contencioso sobre la reciprocidad en materia de enseñanza y la situación de los establecimientos docentes en ambos países en DELGADO, $L$. y Niño, A., “Emigración, enseñanza y nacionalidad...", págs. 79-101. 
bastante que la persona encargada de la dirección del centro fuese de origen irlandés y católico ${ }^{29}$. Menor fue la dedicación que concedieron los Estados Unidos a estas cuestiones en aquellos momentos. Es más, los intercambios culturales hispano-norteamericanos se vieron perturbados por las trabas y dilaciones burocráticas que pusieron algunas dependencias oficiales españolas a la entrada de periódicos y libros de aquella nación y, además, por la censura cinematográfica impuesta sobre las películas en que participasen una serie de personajes famosos que habian apoyado al bando republicano durante la guerra civil. El cine, precisamente, estaba destinado a convertirse en un medio privilegiado de propaganda norteamericana en España, aunque la preocupación de Estados Unidos por incentivar su presencia en este campo fue algo posterior. Por otro lado, el Consejo Superior de Investigaciones Científicas se preocupó desde fecha temprana por establecer vínculos con organismos análogos tanto británicos como norteamericanos, especialmente con estos últimos, a la vez que se ocupaba de divulgar las actividades de sus diferentes centros. Esa labor supondría una magnífica plataforma cuando los acontecimientos internacionales llevaron a la dictadura española a cifrar sus expectativas de aceptación internacional en las naciones anglosajonas, algo que ocurriría sólo unos años después.

Por lo que afecta a América Latina, otro de los ejes de actuación preferentes, también es posible advertir que esta región se convirtió en una caja de resonancia excepcional del papel instrumental asignado a la expansión cultural por la política exterior franquista. La cautela inicial en este ámbito dejó paso a posiciones más beligerantes, en consonancia con los cambios producidos en el panorama internacional.

Las victorias del Eje en Europa en los primeros años de la guerra mundial espolearon a los dirigentes franquistas. La creación del Consejo de la Hispanidad fue el producto de una corriente de irredentismo moral español ante sus ex-colonias, que cobró intensidad en los momentos de efervescencia de la tentación de incorporarse al conflicto bélico. Con ese organismo se pretendia centralizar bajo una sola dirección el conjunto de las relaciones con los países de América, aplicar una política más decidida y ambiciosa, a la vez que se asumían los presupuestos falangistas de que España debia convertirse en el "eje espiritual del mundo hispánico" y

29 BERDAH, J.F., «La «propaganda» cultural británica en España durante la Segunda Guerra Mundial a través de la acción del «British Council»: un aspecto de las relaciones hispano-británicas (1939-1946)", en Tusell, J., Sueiro, S., Marín, J. M. y Casanova, M., El régimen de Franco (1936-1975). Politica y Relaciones Exteriores, Madrid, UNED, 1993, t. II, págs. 273-286. 
empeñarse en lograr la «unificación de la cultura, los intereses económicos y de poder". Ese ascendiente falangista también se manifestó en su grupo directivo, que desplazó el anterior protagonismo del estamento diplomático en las relaciones culturales con aquella región. En el establecimiento del Consejo influyó, además, el propósito de aprovechar el potencial aglutinador de España en el subcontinente americano como una palanca que afianzara su posición en la Europa fascista. Si por un lado se reivindicaba una identidad colectiva cimentada en la Hispanidad, por el otro era patente la dimensión anti-norteamericana que llevaba incorporada y su sincronia instrumental con los objetivos de las naciones del Eje. Para éstas, la colaboración española suponía un recurso que podía emplearse para impedir la alianza continental americana promocionada por los Estados Unidos y para mitigar la ofensiva contraria al Eje que se desarrollaba en varios paises de la zona ${ }^{30}$. Para el régimen español, que no habia conseguido que sus camaradas fascistas aceptaran por el momento sus demandas expansionistas en el norte de Africa, la dimensión atlántica representaba, a corto plazo, una de las vías que permanecian abiertas a su posible influencia sin llegar a afrontar el comprometido trance de la implicación bélica efectiva. Un ámbito de acción donde sus intereses eran complementarios a los de las naciones a que pretendía asociarse y, por eso mismo, una baza a jugar por la débil dictadura española ante sus poderosos aliados europeos con vistas a una rentabilidad política posterior. En cualquier caso, el régimen franquista tenia una política particular en este ámbito, que no excluia la cooperación coyuntural con los móviles germano-italianos, pero que traducia fundamentalmente un proyecto propio de fachada cultural-espiritual y transfondo político ${ }^{31}$.

30 De hecho, en la prensa alemana se hacian conjeturas sobre una España que representaria el tercer pilar del Orden Nuevo, con Alemania como centro de poder continental, Italia como núcleo básico del Mediterráneo y España en calidad de cabeza de puente hacia Africa del Norte y el Atlántico. Vid. "La presse allemande et le role de l'Espagne dans l'ordre nouveau (Afrique du Nord et Atlantique)", 27-IX-1940. AD-MAE, Papiers 1940-1941, Bureau d'Etudes Chauvel, Espagne, vol. 36. También la diplomacia italiana era consciente del papel que España podia jugar en la contención de las tendencias panamericanistas de los Estados Unidos. Vid. "Consiglio della Hispanidad", 2-XII 1940; "Spagna e Stati Uniti d'America", 24-XII-1940, y "Azione della Spagna in Sud America", 23 X-1942. ASD-MAE, Affari Politici 1931-1945, B 60/1.1 y B-63/3. La función de España como cabeza de puente en América no era, por otra parte, algo novedoso ni para la politica exterior alemana ni para la italiana, pues ambas venían contemplando esta posibilidad ya desde los años veinte.

31 El régimen franquista declinó casi siempre la colaboración directa con Alemania e Italia en América Latina, consciente de que esa línea de conducta le podría reportar más perjuicios que beneficios. Por ejemplo, ante un ambicioso proyecto de cooperación italo-española formulado por el gobierno de Mussolini, dirigido a la expansión de las publicaciones de ambos países en América, la respuesta española fue el silencio. Vid. la documentación recogida en AMAE, R-2.170/1 y ASD MAE, Affari Politici, B-60/1.2. 
Puesto que los Estados Unidos habian usurpado el lugar de España en América, incluso en un terreno que le era tan privativo como el cultural, se hacia preciso combatir su influjo para que volver a ocupar el papel que le correspondia en razón de su afinidad histórica, racial, cultural y religiosa con aquella región ${ }^{32}$. La dictadura franquista, integrada en la Europa emergente cimentada sobre la supremacía militar de las potencias de Eje, aspiraba a convertirse en el interlocutor privilegiado entre el nuevo centro de poder mundial que se estaba fraguando y las naciones del otro lado del Atlántico a las que estaba ligada por su secular parentesco. La Hispanidad como estrategia cultural en los primeros años cuarenta no se concebía como un elemento sustitutivo de la actuación política directa, sino como un estadio de preparación y consolidación ideológica de los fundamentos en que ésta habría de cimentarse. Ante la conveniencia de sortear la oleada antifascista que recorría aquella zona, la acción cultural suponía un medio de continuar la labor de atracción ideológica entre las élites latinoamericanas y de las colonias españolas, actuando a menudo como pantalla que ocultaba motivaciones de índole claramente política y por ello más polémicas, e incluso como un polo de atracción que sirviera de soporte a las mismas. Por tal procedimiento esperaba obtenerse una mayor capacidad expansiva y agrupar a un amplio movimiento de opinión favorable en torno al proyecto comunitario promovido por la España franquista. Sin embargo, el resultado de esa actuación, que privilegió ostensiblemente la dimensión política sobre la cultural, fue el contrario. Despertó primero las reticencias y después el antagonismo de los Estados Unidos y, paralelamente, condujo al alejamiento del régimen de buena parte de sus anteriores partidarios al otro lado del Atlántico ${ }^{33}$.

32 Una muestra representativa de los llamamientos dirigidos a las élites intelectuales españolas y latinoamericanas para que reaccionasen ante la amenaza de invasión cultural norteamericana en el mundo hispánico puede observarse en los editoriales "Peligros del español", "La política cultural hispano americana" y "Aviso fraterno a los jóvenes americanos", de la revista Escorial, 7 (1941), págs. 161-166, 11(1941), págs. 325-330, y 14 (1941), págs.315-320, respectivamente.

33 La evolución de las relaciones culturales entre España y América Latina ha sido objeto de varias publicaciones del autor de estas líneas, remitimos a ellas para un análisis más en profundidad. Vid. Delgado Gómez-Escalonilla, L., Diplomacia franquista y politica cultural hacia Iberoamérica, 1939-1953, Madrid, CSIC, 1988; "Percepciones y estrategias culturales españolas hacia América Latina durante la Segunda Guerra Mundial», Estudios Interdisciplinarios de América Latina y el Caribe, vol. 2, 2 (1991), págs. 5-23; Imperio de papel..., págs. 117-156 y 237 y ss., y "Entre la Hispanidad beligerante y la Comunidad Hispánica de Naciones (19391953)", en España/América Latina: un siglo..., págs. 91-136. Otras aportaciones complementarias a esos trabajos, en torno a la difusión propagandistica falangista o a la política exterior franquista, en Gonzalez Calleja, E. y Limon Nevado, F., La Hispanidad como instrumento de combate. Raza e Imperio en la prensa franquista durante la guerra civil española, Madrid, CSIC, 1988; GonzAlez CAILEJA, E., “El servicio exterior de Falange y la política exterior del primer franquismo: 


\section{RUMBO A LA POSTGUERRA: ESPAÑA ES DIFERENTE}

El cambio que se registró en el desarrollo de los acontecimientos bélicos a finales de 1942, unido a la propia dinámica interna de la política española, irian modificando, no sin resistencias en el seno de las familias del régimen, la anterior proclividad hacia el Eje de la política exterior. El curso posterior de la guerra fortaleció las corrientes neutralistas, poniéndose el acento en el carácter católico y anticomunista del franquismo. La entente peninsular con Portugal y la confección de un plan de paz negociada en Europa fueron la manifestación preliminar de esa conducta. En un sentido análogo, dirigido a resaltar la singularización española frente al Eje, hay que situar la política americanista que empezó a aplicarse meses más tarde. La dimensión cultural también estuvo presente en ese reajuste táctico.

Previamente, en el último trimestre de 1942, se habia planteado una reorganización institucional de los servicios que se ocupaban de las relaciones culturales con el extranjero. Se trataba básicamente de sacar de su inactividad a la Junta de Relaciones Culturales y de transformar el Consejo de la Hispanidad en un Instituto de la Hispanidad. Con ello se quería aprovechar el potencial de la política cultural como via de intervención para enmendar la complicada situación internacional española, y a la vez conseguir que fuera el Ministerio de Asuntos Exteriores quien ejerciera el protagonismo absoluto en la planificación de esta materia. Ambas propuestas, elevadas desde la Sección de Relaciones Culturales, fueron desestimadas. Por el momento no se consideraba indispensable la aportación de la Junta, que podría volver a motivar las discusiones en torno al reparto de competencias en la institución. Tampoco se estimaba pertinente la metamorfosis recomendada para el Consejo de la Hispanidad, que tenía como objetivo atenuar las críticas suscitadas al otro lado del Atlántico por asimilársele a un instrumento de propaganda pro-fascista y anti-norteamericana. El control de este organismo por el Ministerio de Asuntos Exteriores era la solución considerada más viable, a la par que se arrinconaban los contenidos beligerantes que habían presidido su gestación y se eliminaba la anterior influencia del grupo de dirigentes falangistas.

consideraciones previas para su investigación», Hispania, 186 (1994). págs. 279-307; PARDO SANz, R., “Hispanoamérica en la política nacionalista, 1936-1939", Espacio, Tiempo y Forma, Serie V, Historia Contemporánea, 5 (1992), págs. 211-238, y la obra de esta última autora que aparecerá próximamente Con Franco hacia el imperio. La política española en América Latina (1939-1945). Madrid, UNED, 1995. 
A pesar de que no se llevaran a cabo medidas drásticas que pusieran de relieve cambios notables en la orientación de la política exterior, si que se dieron de forma más discreta ciertos pasos en la dirección aconsejada por los servicios culturales. Es más, en este sentido cabe apreciar que la política cultural estaba destinada a ocupar un destacado lugar en el reajuste de las relaciones con América Latina que la dictadura franquista comenzó a desplegar desde mediados de 1943. La progresiva analogia con aquella región suponia una de las bazas del régimen para afirmar su problemática diferenciación respecto a las naciones del Eje. Sin embargo, un considerable sector de la opinión pública de las repúblicas latinoamericanas mostraba una marcada desconfianza, cuando no hostilidad, hacia el régimen. Esa era además la tónica imperante tanto entre la emigración española como entre los grupos católicos americanos, considerados ambos como los principales aliados potenciales. Tal actitud dificultaba los intentos de aproximación directa. Por ello, se pensó que la forma más factible de desarrollar la rectificación americana del régimen era colocarla bajo el manto cultural. La táctica diseñada en aquellos momentos consistió en la puesta en marcha, todavia incipiente, de una política cultural destinada a propagar «insensible e inadvertidamente" lo que denominaban la verdad de España. Para lograrlo, se apelaba a la tradición, el catolicismo y el anticomunismo como elementos distintivos, se marcaban distancias con los regímenes fascistas, y se preveía realizar una movilización de las energías científicas e intelectuales al servicio del Estado. Por el momento, para limar asperezas con las naciones aliadas, dejó de cuestionarse la hegemonia de los Estados Unidos en el hemisferio occidental, y se insistió en que el campo de acción español se limitaba al terreno de 10 cultural y lo religioso ${ }^{34}$.

En la segunda mitad de ese año tendría lugar la agonía del régimen fascista italiano, cuya dramática liquidación sirvió de advertencia para quienes ocupaban el poder en España; también empezaban a advertirse señales de que la oposición exiliada trataba de constituir una plataforma unitaria antifranquista. A partir de entonces, cobrarían una creciente intensidad los alegatos sobre la originalidad del Movimiento español, sobre la desvinculación del autoritarismo católico español de otros sistemas totalitarios

34 Para una recapitulación sintética sobre el contenido y repercusiones posteriores de esa programación de politica cultural americanista vid. DELGADO GómEZ-ESCALONILLA, L., "El recurso al "mundo hispánico»: elaboración y trayectoria de una politica de sustitución", en El régimen de Franco ..., t. Il, págs. 515-533. Una exposición más completa de las consecuencias que tuvo sobre la política cultural el cambio gradual de la política exterior franquista en los años finales de la guerra mundial, en la obra del mismo autor Imperio de papel..., págs. 319-392. 
europeos, o sobre su neutralidad a lo largo de la guerra mundial ${ }^{35}$. Una coartada justificativa que haría escasa mella en las naciones aliadas a corto plazo, pero que estaba destinada a tener una curiosa longevidad, con sucesivas transformaciones, para permitir afirmar que la dictadura franquista era la solución política más conveniente dado que a fin de cuentas España era diferente.

Uno de los procedimientos empleados para hacer tabla rasa del pasado filofascista del régimen, para apoyar esa coartada sobre la originalidad del Movimiento español, fue demostrar una mayor tolerancia hacia las actividades culturales de las naciones anglosajonas, algo que se hizo más patente a medida que se confirmaba el avance aliado. La propaganda de tipo cultural que realizaban Gran Bretaña y los Estados Unidos se había venido incrementando paulatinamente, conscientes de la importancia que tenia la neutralidad española para sus planes de ofensiva militar en el norte de Africa y en el flanco sur de Europa. Por medio de esa propaganda cultural se disponía de circuitos que permitian estrechar los contactos con los sectores dirigentes del régimen menos proclives al Eje, y que amplificaban así el eco de otras iniciativas propagandísticas dirigidas a los medios informativos. Mientras que Gran Bretaña se dedicó a continuar la línea emprendida tiempo atrás, el cambio de actitud de los Estados Unidos resultó mucho más significativo.

Con una dedicación inicial hacia los sectores económicos españoles, que después se ampliaría a los medios católicos, la intervención norteamericana fue ganando posiciones en el panorama cultural español. La apertura de una biblioteca en Madrid, acompañada más tarde de la creación de la Casa Americana y del nombramiento de un Agregado cultural, y que se completarían con el recurso a la intensificación de la presencia cinematográfica norteamericana, posibilitaron un espectacular crecimiento de la audiencia que encontraban las producciones culturales de este pais

35 Algo que ya habia comenzado a vislumbrarse con cierta antelación en el cambio de tono de algunas publicaciones destinadas a crear opinión entre los medios dirigentes españoles. Vid. "Más sobre España", Escorial, 20 (1942), págs. 315-319; Garcia Valdecasas, A., "Los Estados totalitarios y el Estado español", y LunA, A. de, "España, Europa y la Cristiandad", ambos en Revista de Estudios Políticos, 5 (1942), págs. 5-32, y 9 (1943), págs. 41-98. Aunque lo cierto es que hasta avanzado 1943 no se manifestaria de una forma plenamente definida, con una singular resonancia en los editoriales del semanario El Español, publicación de la Delegación Nacional de Prensa. Vid. Rio Cisneros, A., Viraje político español durante la ll Guerra Mundial 1942-1945. Réplica al cerco internacional 1945-1946, Madrid, Eds. Europa, 1977. 
en España ${ }^{36}$. Por otra parte, los vínculos culturales de España con Alemania e Italia experimentaron una sensible disminución al hilo del desarrollo de los acontecimientos bélicos, desfavorable para ambas naciones, con las repercusiones de todo orden que ello ocasionó. Tal circunstancia se conjugaba también para favorecer una mayor pujanza anglosajona y, al acabar la guerra mundial, la influencia cultural británica y norteamericana en España había adquirido una ventajosa posición que los dos países se encargarían de consolidar posteriormente ${ }^{37}$.

A comienzos de 1945, las previsiones de la política exterior española conceptuaban precisamente a Gran Bretaña como el interlocutor de una deseable alianza en Europa, y a los Estados Unidos como potencial refuerzo de esa inclinación. Tales previsiones estaban avaladas por la confianza en una ruptura de ambos países con su aliado soviético, que favorecería la anuencia hacia ese neutral sospechoso que era el franquismo. Aún más, llegaron a elaborarse proyectos dirigidos a establecer una coordinación atlántica, en la que junto a Estados Unidos, Gran Bretaña, Portugal y América Latina participaría obviamente España, en calidad de nación integrante del mundo hispánico ${ }^{38}$. Sin embargo, en lugar de la apetecida admisión en los resortes de la estructura internacional de la postguerra, la dictadura hubo de enfrentarse a una agudización de la condena exterior. Para las naciones anglosajonas era muy difícil hacer digerir a sus respectivas opiniones públicas la viabilidad de entenderse con un régimen político engendrado con el apoyo de sus adversarios.

Una de las medidas que se tomaron para hacer frente a esa situación fue el relanzamiento de la política cultural, siguiendo las pautas elaboradas originariamente para su aplicación en el subcontinente americano. Desde

36. Esas actividades no pasaron desapercibidas para la diplomacia de otros paises que aspiraban a mantener una influencia cultural en España, vid. a título ilustrativo "Attivita culturale degli Stati Uniti in Spagna», 6-X-1942 (ASD-MAE, Affari Politici, 1931-1945, B-62/1.13), y "Propagande anglo américaine en Espagne", 10-lll-1943 (AD-MAE, Vichy Europe 1939-1945, Espagne, vol. 252). Sobre el incremento de la presencia cinematográfica norteamericana en España y su contribución a la tareas propagandísticas vid. PIZARRoso Quintero, A., «El cine americano en España durante la Segunda Guerra Mundial: información y propaganda", Revista Española de Estudios Norteamericanos, 7 (1994), págs. 121-155.

37 Resulta muy representativo a este respecto el diagnóstico que hacia tan sólo unos años después la diplomacia francesa, siempre preocupada por mantener una situación de predominio cultural en España, al analizar la incidencia de la guerra mundial y la inmediata postguerra en las relaciones culturales de España con algunos de sus principales interlocutores internacionales. "Propagande culturelle espagnole. Position des pays étrangeres et de la France", 19-VII-1947 AD-MAE, Amérique 1944-1952, Généralités, vol. 96.

38 Sobre esos cálculos de la diplomacia española vid. los informes "Coordinación atlántica», X-1944, y “La situación internacional en enero de 1945", I9-I-1945. AMAE, R-1.370/10. 
mediados de 1945, casi simultáneamente con el final de la guerra, esa política cultural cobró un acusado relieve, pero ahora su radio de acción afectó al conjunto de la política exterior franquista ${ }^{39}$.

Para empezar, aumentó de forma espectacular la cantidad económica destinada a esta materia, con la concesión de un crédito extraordinario de cuarenta millones de pesetas, cantidad que quintuplicaba el presupuesto ordinario dedicado a las relaciones culturales con el extranjero y que equivalía a casi un $40 \%$ del presupuesto del Ministerio de Asuntos Exteriores para ese año. Además, los organismos encargados de la política cultural fueron reorganizados, con la revitalización de la Junta de Relaciones Culturales que llevaba sin reunirse desde la guerra civil, la creación de la Dirección General de Relaciones Culturales, y la sustitución del Consejo de la Hispanidad por el Instituto de Cultura Hispánica. Desaparecian pues escrúpulos anteriores ante la recuperación de la mencionada Junta, o ante la transformación del Consejo de la Hispanidad en una entidad que no recordara los ecos negativos que aquél había suscitado. Las premisas básicas de tales modificaciones fueron, en definitiva, las avanzadas en el frustrado proyecto de reforma de finales de 1942. Junto a lo anterior, se apreció una clara redefinición de los centros de interés fundamentales de la política cultural.

En lo sucesivo esos centros de interés fueron Gran Bretaña, los Estados Unidos y América Latina. Las dos grandes potencias occidentales triunfadoras en la contienda mundial desplazaban pues el ascendiente previo de Alemania e Italia como polos de referencia cultural. En cuanto a América Latina, en aquellos instantes concentraba el núcleo más activo de la oposición exiliada, así que era preciso contrarrestar esa influencia negativa, cuestión de la que se ocupó el Instituto de Cultura Hispánica mediante una estrategia de captación selectiva. En ambos casos, el principal argumento que rodeó la aportación de la política cultural a la estrategia de perduración del régimen fue la defensa católica.

El relanzamiento de la política cultural estuvo asociado a ese protagonismo de la invocación católica. Su objetivo primordial fue explotar sus efectos socializadores como instrumento de legitimación ideológica en un contexto internacional marcadamente desfavorable. La acción cultural se plegó una vez más a los requerimientos de la política exterior, a la necesidad de obtener el respaldo católico para disminuir la repulsa internacional

39 Las coordenadas generales de ese relanzamiento de la politica cultural en DELGADO GómEzEscalonilla, L., Imperio de papel..., págs. 419-462. 
contra la dictadura, al propósito de favorecer la connivencia anglosajona para superar su marginación de las coordenadas políticas de la postguerra. Todo ello contribuyó a acentuar la simbiosis entre acción cultural y propaganda. El régimen dispuso por esta vía de un medio encubierto para difundir la verdad de España sin despertar las suspicacias de sus receptores; para cooperar a la atracción hacia su causa de sectores interesados por su cultura o ideológicamente afines, aunque reticentes ante su sistema político; en suma, para facilitar su apología en el exterior evitando las réplicas contraproducentes de una propaganda directa.

Sin duda uno de los elementos claves que hizo posible la efectividad de esa política cultural fue la implicación en su desarrollo de miembros del catolicismo colaboracionista español. La opción católica, tras la incorporación de una de sus figuras más relevantes a la cartera de Asuntos Exteriores, se perfiló como el pararrayos de la dictadura en el panorama internacional. El compromiso del catolicismo colaboracionista no era ajeno a una cierta perspectiva de cambio político limitado, pero en cualquier caso no rehuyó ocupar la primera línea en la defensa del franquismo más alla de las fronteras nacionales, asumiendo una diplomacia paralela entre los círculos católicos europeos y americanos ${ }^{40}$. Buena muestra de ello puede advertirse tanto en la participación directiva de esos medios católicos en el Instituto de Cultura Hispánica, como en la influencia que ejercieron los representantes del Consejo Superior de Investigaciones Científicas en la Junta de Relaciones Culturales y, en consecuencia, sobre la planificación y gestión de las relaciones culturales de España con el extranjero ${ }^{41}$.

En la segunda mitad de los años cuarenta el régimen franquista hubo de afrontar una de las coyunturas más complicadas de su larga singladura. En ese período de cuarentena internacional se aplicó la consigna de "orden, unidad y aguantar" ${ }^{42}$. Mientras tanto, la politica cultural desempeñó un destacado papel en la tarea de remover los obstáculos que se

40 Esa colaboración política y cultural de un importante sector del catolicismo español con el régimen ha sido estudiada por HERMET, G., Les catholiques dans I 'Espagne franquiste. Les acteurs du jeu politique, Paris, FNSP, 1981; TusELL, J., Franco y los católicos. La política interior española entre 1945 y 1957. Madrid, Alianza, 1984; Botтı, A., Nazionalcattolicesimo e Spagna nuova (1881-1975), Milano, Angeli, 1992, y FERAARY, A., El franquismo: minorias políticas y conflictos ideológicos (1936-1956), Pamplona, EUNSA, 1993.

41 Sobre la actuación del Instituto de Cultura Hispánica y la Junta de Relaciones Culturales en la postguerra mundial vid. Delgado Gomez-ESCALONILLA, L., Diplomacia franquista y política cultural..., págs. 109-227.

42 El contexto que rodeó a la formulación y ejecución de esa línea de conducta propuesta por el almirante Carrero Blanco ha sido analizado recientemente en la obra de TusELL, J., Carrero. La eminencia gris del régimen de Franco, Madrid, Eds. Temas de Hoy, 1993, págs. 107-176. 
oponían a su aceptación exterior. No fue una labor cuyos resultados puedan evaluarse de forma nítida y cuantificable, pero desde luego sí que es posible apreciar algunos de los efectos que llevó aparejada. Esa política constituyó un medio de captar apoyos para la rehabilitación internacional del régimen, una vía para divulgar en el exterior una imagen edulcorada de la dictadura española, un ámbito del que extraer argumentos sublimadores de cara a la opinión pública interior; en suma, una ventana entreabierta al mundo durante la travesia del desierto del franquismo ${ }^{43}$.

43 No resulta casual a este respecto que el Ministro español de Asuntos Exteriores expresara su reconocimiento a la intervención del "frente del pensamiento y la cultura" - en la ruptura del aislamiento internacional del régimen. MARTIN ARTAJO, A., La política internacional de España en 1945-1950, Madrid, Oficina de Información Diplomática, 1950. 


\title{
Información y desinformación. La II guerra mundial a través del NO-DO
}

\author{
Josefina MARTÍNEZ
}

\section{INTRODUCCIÓN}

El primer lunes de 1943, unos acordes compuestos por el maestro Parada y una campanas al vuelo seguidas de un águila imperial sorprendían los oídos y los ojos de aquellos españoles que, guarecidos del frío y para olvidar el hambre, se encontraban en las 4.000 salas de cine que entonces habia en el territorio nacional.

Chicos y grandes se desconcertaron ante una narración en perfecto castellano sin ese deje gangoso de los noticiarios de la FOX, la dureza del acento en los reportajes de la UFA o el tono más melódico del castellano hablado por cronistas del LUCE italiano. También las imágenes eran más cercanas. El NO-DO se estrenaba en su n 1 con el ambiente navideño de la plaza Mayor de Madrid, unas jovencitas sonrientes que cerraban paquetes para los voluntarios de la División Azul, un partido de fútbol entre la selección aérea italiana y nuestro Atlético de Aviación, una demostración deportiva en Berlín, los nuevos peinados de París, la cosecha algodonera en Ucrania, una misión comercial española en Argentina, la llegada de Muñoz Grandes desde el frente en olor de multitud, Franco entregando despachos a los nuevos oficiales del Estado Mayor, el día de acción de gracias en Londres, un desfile de tropas ante Hiro-Hito y, para terminar, el frente de guerra en el Cáucaso y en el sector central soviético.

Sin saberlo, los espectadores asistían al nacimiento del noticiario español que en este número mostraba una sintesis de todos los temas que, al menos durante los tres años restantes, coparian los primeros 15 minutos de las ansiadas sesiones de cine. A partir de este momento y durante 32 años, hasta septiembre de 1975, NO-DO tendría el monopolio de la información cinematográfica de actualidad que se proyectase en nuestro país. 
Por una orden de la Vicesecretaria de Educación Popular del 17 de diciembre de 1942, (“BOE» del 22 de diciembre), firmada por Gabriel Arias Salgado, se crea "la entidad de carácter oficial Noticiarios y Documentales Cinematográficos NO-DO (...) que editará y explotará, con carácter exclusivo, el Noticiario Cinematográfico Español (...) siendo este organismo el único que en el futuro podrá llevar a cabo el intercambio de noticias cinematográficas con el extranjero".

La orden continuaba con 5 escuetos artículos en los cuales se añadia que - a partir de ese momento- en ningún punto de España y sus colonias se podia proyectar otro noticiario que no fuera el NO-DO, ningún operador podía obtener reportajes y ningún laboratorio manipularlos sin la autorización de NO-DO y se establecía la obligatoriedad de su exhibición en todos los locales cinematográficos del territorio nacional.

Con las consignas de instruir, informar y entretener a todos los españoles nacia el noticiario español NO-DO. El Régimen, tras una guerra civil e inmerso en la guerra europea - de forma neutral o no beligerante, según los momentos-, necesitaba de un órgano propio de información audiovisual y, por fin, ya lo tenía.

\section{¿DE DÓNDE PROCEDE LA INFORMACIÓN?}

A pesar de esta orden y de que fueran nacionalizados todos los elementos de los distintos noticiarios que elaboraban reportajes de España para el exterior UFA, LUCE, FOX MOVIETONE, etc., no resultó tan sencillo poner en funcionamiento el proyecto. En primer lugar, en España no se fabricaba pelicula virgen, por lo que se dependía de las importaciones y, con la guerra, resultaba difícil conseguir las partidas; en segundo lugar, no contaba NO-DO con laboratorios propios que pudieran positivar y montar los negativos. Ambas carencias fueron satisfechas. De Alemania venía la película virgen para rodar y, después, en los laboratorios madrileños Riera y Madrid Films, se empezó a positivar el negativo, que iría

\footnotetext{
Asimismo, en el Deutsche Wochenschau aparecen varias noticias relativas a España: la reunión en Hendaya de Hitler y Franco ( $A X$ 120); la visita de Serrano Súñer a Berchstengaden para entrevistarse con Ribbentrop, Ciano, Keitel y Hitler (AX 247) en noviembre de 1940 o la reunión de Mussolini y Franco en Bordighera el 12 de febrero de 1941. Existe un documental de la Acción Nacional Suiza contra el Comunismo titulado "La peste roja» dedicándose cerca de 20 minutos a la guerra civil española, donde se expone la evolución del conflicto y remarcando que España es uno de los antecedentes del conflicto mundial (AX 235). Todas ellas se conservan en el archivo de NO-DO y aqui se indica su número de signatura.
} 
después acompañado de las noticias venidas del extranjero. Aquí se les ponía el texto, la voz en off, se limaba ligeramente la imagen para acoplar el sonido y se acomodaban las locuciones de las arengas triunfalistas tanto de los noticieros alemanes como, posteriormente, los reportajes estadounidenses o británicos con el fin de que resultasen más asépticos ${ }^{2}$.

Hasta mediados de 1951, año en que NO-DO tiene ya sus propias instalaciones, el noticiario se realiza de este modo. No es de extrañar que la información sobre los aliados sea menor. Antes del número 23a -junio de 1943 - con una noticia sobre Leslie Howard (muere al ser alcanzado su avión por los alemanes ${ }^{3}$ ) y el $25 \mathrm{~b}$ en que aparecen las nuevas lanchas salvavidas, no se da ni una sola noticia de Estados Unidos o los países aliados en lo tocante al conflicto bélico.

Un 40 por ciento de los números que exhibe el NO-DO desde enero de 1943 hasta enero de 1946 se ocupan de la Segunda Guerra Mundial. En los 181 números que abarca este período, tanto en la versión $A$ como $B$ del noticiario, el conflicto bélico será el tema dominante. De las 52 horas que suma este material, cerca de 20 horas se dedican a él. En la mayoría de los números de NO-DO hasta la victoria sobre el Japón (142a), de los 8 reportajes que ofrecía el noticiario, al menos 3 se referían al conflicto bélico. Las insulsos reportajes nacionales o internacionales de bailes y bodas típicas, acontecimientos deportivos o taurinos, modas, inventos o actos oficiales no tienen el menor peso especifico frente a los reportajes de guerra.

Lógicamente, la información va evolucionando en el mismo sentido que la propia guerra, aunque cuesta separarse de la tendencia germanófila ${ }^{4}$. La dirección de NO-DO, que hasta el desembarco en Sicilia (40a) ha mantenido la tónica de dar noticias de, sobre y venidas de Alemania, se vuelve más «imparcial». Se empiezan a montar más imágenes sobre los aliados, sin perder "la objetividad", presentando -en principio- tanto la victoria del Reich como la aliada en cualquiera de los reportajes. Ambos

\footnotetext{
2 Todo este proceso se aprecia en algunos reportajes que se han conservado con el sonido original al perderse o reutilizarse la banda sonora española.

3 Los aliados conocian las claves de radio alemanas desde principios de 1943. Gracias a eso descifraron un mensaje en el que se decia que el avión que trasladaba a Leslie Howard a Londres, después de dar una serie de conferencias en favor de los aliados, iba a ser derribado. Se vieron en la disyuntiva de salvar al actor o no mostrar sus conocimientos, optando por lo segundo.

4 Se ha negado en varias ocasiones la tendencia germanófila del NO-DO - declaraciones de Alberto Reig, subdirector del noticiario en sus origenes y posteriormente director- y $V$. SANCHEZ Biosca y R.R. Tranche: NO-DO: El tiempo y la memoria. Madrid. Filmoteca Española, 1993, p. 35, pero, tras nuestro visionado y análisis, no to consideramos así.
} 
contrincantes cumplen siempre con los objetivos marcados. A partir de enero de 1944, y de forma gradual, un lenguaje más aséptico, sobre todo en los frentes europeos, y una construcción en cada número del noticiario más equilibrada se impondrá en la manera de elaborar el noticiario que ya ofrece una noticia procedente de Alemania y una inglesa o norteamericana. Esta estructura se mantendrá hasta el final de la contienda, no habrá vencedores ni vencidos en Europa, la ecuanimidad perdura durante toda la guerra, ¿pero, qué guerra?

\section{LA GUERRA DE LOS ESPAÑOLES}

Queda claro, a través de múltiples informaciones del noticiario, que la guerra civil española es el inicio de la cruzada contra el comunismo que supone la II Guerra Mundial. Reportajes sobre el discurso de Franco en la apertura de las Cortes de 1943 (13); varios recordatorios titulados “'Españoles, acordaos!” $(14,22 a)$, donde se mezclan imágenes de la guerra civil, de Paracuellos y el descubrimiento de la fosa de Katyn en Polonia; la imposición de la Medalla de la Ciudad de Madrid a Franco (15); el discurso de Jordana en las fiestas colombinas de 1943 (18) o la reconstrucción de las fábricas de Sabadell destruidas por "las hordas marxistas (...) legado siniestro de la revolución roja" (29a) son motivos suficientes para explicar - a través de la imagen y la palabra- que España paró «la revolución roja» y que Franco "liberó a España de esta carroña" (30b). Ahora es el turno de Alemania de defender a Europa, desde las posiciones conquistadas en el Este, del "peligro rojo".

Pero España, a pesar de haber defendido su territorio del comunismo y haberlo liberado de este peligro, no se desentiende del drama europeo. El gobierno español, que aparece en varios reportajes del NO-DO, reiterará en todo momento su "estricta neutralidad" durante todo el conflicto. Informa a los espectadores de su actitud de «no ceder ante ninguna presión para mantener nuestra posición» (59a), a la vez que "España se mantiene en orden y paz bajo el signo del Caudillo" (105b).

Aún así, España participará en la guerra de forma activa al enviar a Rusia la División Azul o de manera más tangencial con misiones humanitarias. En el momento de nacer el NO-DO, los voluntarios están casi por volver. En el primer número hay dos reportajes referidos a ellos, tal y como se ha señalado más arriba: preparación de regalos de navidad para enviar a los divisionarios y regreso de Muñoz Grandes del frente. Dos números después, podemos ver como Muñoz Grandes es condecorado por Hitler con las hojas de roble de Caballero de la Cruz de Hierro por su heroica 
labor. Varios números posteriores los ocupan las visitas de Esteban infantes a las tropas en el frente $(19,23 b, 28 a)$, asi como una entrevista de Lindemann y Esteban Infantes (31a) y la visita de la madrina de la División, Celia Jiménez a los voluntarios (5). A los soldados apenas se les ve en acción (sólo en el $n^{\circ} 7$, luchando en primera línea «sin importarles el fragor de la batalla ni la dureza del terreno"), sí se ve cómo se les condecora, forman, juegan con la nieve, oyen misa y regresan sanos y salvos a Irún $(19,23 b, 28 a)$, lo que seguramente tranquilizaría a las familias de los voluntarios. Desgraciadamente muchas de estas imágenes eran de dos años antes: formaban parte de un noticiario de la UFA realizado en 1941 (AX 248) y se montaron para el NO-DO. Fue un claro ejemplo de manipulación informativa.

De los voluntarios que no regresaron en este tren de mediados de 1943 , no se volverá a saber nada hasta el regreso de los 286 prisioneros que después de un cautiverio de entre 11 y 13 años llegarian a Barcelona en el Semíramis el 2 de abril de $1954{ }^{5}$. Posteriormente, en octubre de 1956 llegarán a Valencia otros 532 repatriados de Rusia (718a).

La otra vertiente que se presenta en el NO-DO de la participación española en la guerra mundial, vendrá marcada por su neutralidad. Se trata de los intercambios de prisioneros que se suceden en el puerto de Barcelona. En presencia de la Cruz Roja Española y de los embajadores inglés y alemán tiene lugar un primer intercambio de 2.144 prisioneros y heridos de ambos países. La noticia se verá la segunda semana de noviembre de 1943. Las damas de la Cruz Roja entregan flores y cigarrillos, mientras el cuerpo diplomático saluda afectuosamente a los compatriotas para los que la guerra ha terminado y regresan a sus hogares $(45 a, 45 b)$.

En mayo de 1944 se volverá a efectuar la misma operación en Barcelona bajo la mirada amable y vigilante de la Cruz Roja. Esta vez serán 2.000 heridos alemanes, norteamericanos y británicos los que vuelvan a su patria $(74 b)$.

El último apunte que presenta el NO-DO de las relaciones de España con los paises beligerantes será a través de las diversas noticias del cuerpo diplomático establecido en Madrid. Los reportajes serán escasos:

\footnotetext{
5 Los divisionarios fueron objeto de un documental «La División Azul Española», realizado por Victor de la Serna y Alberto Reig en 1942 que narra -empezando por la guerra civil-el enganche de voluntarios, su llegada a Berlin, acciones bélicas, la vida de los soldados y el relevo de la división ya en Madrid (AX 235). El tono triunfal, la victoria sobre el comunismo y la heroicidad de los voluntarios será el hilo conductor de este documental.
} 
- Las relaciones, más bien de tipo cultural, que se mantienen con Alemania: visita del agregado cultural a la Academia José Antonio (10) y apertura del centro hispano-germano en Madrid (12).

- Representantes norteamericano y británico pasando la frontera de Irún para entrevistarse con el coronel Ortega a mediados de septiembre de 1944 (90a).

- Cambio del embajador italiano por la muerte del Conde Lequio en enero de 1943. Las imágenes mostrarán el funeral y entierro (5). El nuevo embajador presentará sus credenciales a finales de abril (19).

- Relevo en la delegación alemana. En febrero de 1943 se enviará un nuevo ministro plenipotenciario (5), que fallece en Madrid al mes siguiente y sus restos deberán ser trasladados a Alemania. Las honras fúnebres vestirán de banderas nazis toda la Gran Via (14). En abril, el nuevo embajador será recibido por Franco y el conde de Jordana. La Gran Vía, una vez más, tendrá el dudoso honor de engalanarse con svásticas por doquier (20a).

- Muerte en mayo de 1944 del agregado aéreo británico. Un desfile militar acompañará sus restos fúnebres por las calles de Madrid (75a). Poco después llegará su sucesor (76b).

- Llegada al aeropuerto de Barajas, a finales de marzo de 1945, del nuevo embajador americano, momento que toman las cámaras del noticiario (117a). A la semana siguiente presenta sus credenciales ante el Jefe del Estado (118a).

\section{LA GUERRA DE LOS ALEMANES}

A través del NO-DO podemos apreciar la imagen que esta institución tenía de la guerra desde el punto de vista de los alemanes. En principio, el enemigo se encuentra en el frente ruso, es la guerra contra "las hordas asesinas del carnicero Stalin» (22a). Parece que el único enemigo que existe es el comunismo. Los títulos de los reportajes "La lucha contra el comunismo" y "Cruzada contra el comunismo", se repiten en la mayoria de los números hasta el desembarco en Sicilia (40a). A partir de entonces el epígrafe será «En el frente del Este» ó «En el frente germano soviético» y el tema recurrente de la ofensiva contra los bolcheviques - palabra que aparece en la mayoría de los reportajes - pasa a segundo término a partir de los números de enero de 1944.

En ningún momento la Wehrmacht pierde en el frente del Este. Siempre "después de un duro combate en el que las fuerzas alemanas han llevado 
la iniciativa, el puesto ha sido conquistado, las órdenes se han cumplido" (30b). Esta frase sintetiza el discurso general de los reportajes de este frente. Desde el número 1 en que aparecen esquiadores en el Cáucaso realizando "el maravilloso deporte de la muerte", ya sea los stukas que "destruyen los objetivos bolcheviques" $(3,5,10,13,15,19 \ldots)$ o atacan ciudades como Leningrado -denominado constantemente San Petersburgo-, Kuban, Charkov, ya sean los submarinos en el mar del Norte o en el mar Negro, la artillería pesada y ligera, la infantería o los paracaidistas, los alemanes siempre vencen.

Deformada nuestra idea de la guerra por el plano y contraplano de las películas de ficción, aquí nos falta el enemigo. Sólo hay dos reportajes en los que aparecen algunos prisioneros rusos que "serán recluidos en campos de concentración" $(31 b, 32 b)$, primera vez que aparece este término sin el matiz adquirido posteriormente tras el exterminio judio.

Las imágenes de guerra propiamente dichas, en el primer año de NO-DO, son planos generales muy abiertos donde a varios kilómetros caen las bombas o se aprecian los disparos contra los aviones. Parece desmesurada la toma de algunos objetivos: impresionantes baterías se utilizan contra pequeñas cabañas de paja. Nunca se ven muertos, ni rusos ni, por supuesto, alemanes. Sí son más "cinematográficas" las imágenes de aviones alcanzados que caen a tierra (34b, 51b, 52b, $54 a \ldots)$. A partir de Sicilia y Normandía los planos son más cortos y se pueden ver los combates en las calles. El horror es más cercano. Las imágenes bélicas en todos los frentes se vuelven más cruentas y afectan más al espectador.

Siempre serán los “adversarios» los que destruyan en sus bombardeos objetivos no previstos. Serán los bolcheviques los que destrocen iglesias que han de reconstruir los alemanes a su paso por diversas poblaciones (8), pero nunca se identifica en los textos a "los adversarios" - los aliados- que en diversas ciudades europeas, por ejemplo Bruselas, destruyen la ciudad y alcanzan a civiles (46a).

Muchos de los reportajes que se ofrecen, muestran la labor de reconstrucción alemana en los territorios conquistados. Gracias a la invasión alemana, Moravia, Ucrania, Francia «hacia 80 años que no se conseguian cosechas como la de este año" y todas las zonas invadidas van a salir del subdesarrollo. Desde luego aumenta todo tipo de producción agrícola, ganadera y mecánica $(40 \mathrm{~b}, 43 \mathrm{~b}, 52 \mathrm{~b} . .$.$) . También se informa de cómo eran$ las escuelas de oficiales, el adiestramiento de todos los cuerpos de todos los ejércitos, las fábricas, la construcción y el funcionamiento de las armas, la reconstrucción de carreteras, ferrocarriles, telecomunicaciones, 
los beneficios del estado nazi, el cuidado por la infancia, la vida en la retaguardia, su arte, el amor a la familia...

"...La población que no quiere caer en manos bolcheviques y sigue a las tropas con alegría..." (43b). Esta frase -utilizada para describir el éxodo de la población civil- resumiria muchas de las noticias que ofrece el NO-DO de los grupos de jóvenes que se unen a la causa nazi: húngaros que marchan al frente del Este $(1,12)$, el juramento de las juventudes holandesas (12), condecoraciones con cruces de hierro a los soldados finlandeses (12), noruegos y franceses incorporándose a filas (20a), letones y lituanos subiendo a los trenes (20b) e incorporándose voluntariamente al trabajo (78a), cosacos voluntarios (24b), la legión de Flandes y las SS de Bruselas (25b), jóvenes españoles escapados de la URSS que llegan a Berlín (3), camisas negras (44b)... En ningún momento deja la población de participar en el conflicto apoyando la causa nazi. Europa no está invadida, sino salvada del comunismo.

En muy pocos reportajes se dan cifras de bajas en ninguno de los frentes. De destrucción de maquinaria bélica sólo se apunta, en octubre de 1943 que, en dos semanas, en el sector central del frente del Este han sido destruídos 4.300 tanques soviéticos (33a). En este momento será la primera vez que se indique que "los aviones bolcheviques entorpecen el avance alemán", aunque los alemanes infligen "pérdidas constantes a los soviéticos en su maquinaria de guerra" (33b). Ya ha tenido lugar el desembarco en Sicilia, visto en el mismo noticiario desde el lado aliado y alemán. Las noticias que se dan son de avances tanto de unos como de otros. Mes y medio después se vuelve a ver los cúltimos combates en Sicilia" ya únicamente desde el lado británico, donde planeadores "descargan pertrechos para las operaciones defensivas" y "la artilleria alemana se pone en acción para proteger la retirada" (40a). En el cielo siciliano "se desarrollan escenas dramáticas". Las escuadrillas alemanas "refuerzan la retirada, mientras las tropas del Reich luchan" (40b). Será la única vez que el texto y las imágenes den por terminada una batalla en la que los alemanes evacuen una zona. Nunca quedará claro que pasó en África ni en el frente soviético.

\section{a) El frente de África}

La guerra en el frente de África apenas tiene reflejo en el noticiario. En enero de 1943 la situación del norte de África no puede tener un discurso lineal como el que se desarrolla en el frente soviético. La situación no es clara para los alemanes. Ha tenido lugar la contraofensiva del Alamein y, 
al frente de Eisenhower, las tropas angloamericanas han desembarcado en Marruecos y Argelia. Tropas alemanas e italianas, en Túnez, avanzan hacia Taburba (3), lo que ya es recogido por el NO-DO. Pero el Eje es derrotado tras la pérdida de Tripolitania y se mantiene la resistencia en el sur de Gabes y Túnez occidental. Aún así, se presentan a finales de febrero reportajes que muestran el cuartel general germano-italiano en Túnez y una entrevista entre Rommel y Cavallero (7). Dos semanas después se podrán ver combates en el frente de Tánger, así como el desembarco de tropas y municiones (9) y operaciones de un destacamento de vanguardia alemán que es recibido por los habitantes de los poblados de la zona (11). En el siguiente número se ofrece un reportaje sobre contingentes italianos que regresan a Brindisi y Venecia y civiles repatriados, seguido de otra noticia en la que los carros blindados alemanes avanzan hacia el Atlas. Los aviones salen de Sicilia y Túnez y la artilleria opera en el sector norte hasta llegar a Gafsa (13), noticia que se da en la primera semana de abril de 1943. Será la última vez que el NO-DO informe sobre el frente de África. Es como si desapareciera la guerra del mapa. No se informará al mes siguiente de la capitulación del África Korps y la toma de 252.000 prisioneros italo-alemanes.

\section{b) El frente de Italia}

A partir de estos momentos, verano de 1943, el tono triunfal de la guerra, desciende. Se aprecia como en los textos la guerra ya comienza a ser algo dramático que no parece tener fin (34b). Es como si los propios redactores del noticiario empezaran a estar cansados de la cruenta situación que asola al planeta. El lenguaje que, hasta el desembarco en Sicilia habia sido, tanto en los reportajes nacionales como en los venidos de Alemania durante este primer período, duro, despiadado, demoledor, cargado de ira y rencor (lo mismo que los noticiarios originales americanos contra los japoneses, ya algo después) no se traducirá al sonido español en el mismo tono. Los textos hablan menos de la necesidad de la guerra, son menos las veces en que «las tropas alemanas son el más firme baluarte contra la invasión bolchevique" (38b). Desde las pantallas se aboga por la paz con frases que expresan deseos como "cuando acabe la guerra y llegue la paz».

Los sucesos de Italia no fueron un paseo militar. Lo demuestra el gran número de reportajes que se ocupan de la guerra en este territorio. A lo largo de todo el discurso de la redacción del noticiario no hay una toma de postura. Ciertamente, se narran los acontecimientos y se puede apreciar lo 
cruento de las batallas, pero da la sensación de que no se quiere reconocer el retroceso de los alemanes.

En agosto de 1943, una vez desembarcadas las tropas aliadas en Sicilia ( $34 a$ y $34 b$ ), no deja de haber ataques y contraataques de ambos bandos. En el NO-DO, hasta seis semanas después no se considera conquistada Sicilia por los aliados (40a), ya en octubre de 1943. Los alemanes han de replegarse al continente sin abandonar la lucha.

Los reportajes sobre Italia se ofrecerán con una cadencia más lenta, cada dos ó tres semanas, no como los del frente del Este que siguen ocupando casi todos los números. Las noticias llegarán tanto de los noticiarios alemanes como de los norteamericanos, a veces en el mismo número y seguidas.

Aunque los alemanes son saludados por los italianos en su repliegue y "en el sur de Italia las fuerzas del Reich se desprenden del adversario y sus avanzadas combaten en primera línea contra contingentes angloamericanos (...) donde el terreno se disputa palmo a palmo" (43b), al retroceder hacia el norte, en Trieste, vemos a los camisas negras que se incorporan a los ejércitos del Reich (44b). Sin embargo, los bombarderos de la RAF actúan sobre Nápoles bloqueando las comunicaciones (47a) y el $5^{\circ}$ ejército aliado establece una cabeza de puente sobre el Volturno que dará lugar a "una de las fases más importantes de la guerra en Italia» (48b). Rommel aparece en el siguiente reportaje inspeccionando las fortificaciones de la muralla blindada en el norte de Italia y se cestablecen nuevas posiciones para el tiro libre" (49a).

En las siguientes 10 semanas no hay información sobre la guerra en Italia, sólo en enero de 1944 habrá unas imágenes de Mussolini con su nuevo consejo de ministros (53a) y, a mediados de febrero, se incide en la ocupación por angloamericanos de posiciones alemanas - con su defensa antiaérea- en el sur de la península (58a).

Si el desembarco a principios de enero de 1944 en Anzio y la toma de Roma pudieron haber sido cuestión de horas, la indecisión del mando norteamericano provocó una carnicería y el retraso en la llegada de la paz. Dieron tiempo a los alemanes a reforzar sus defensas en Monte Cassino lo que hizo que, del 15 de febrero al 30 de mayo la guerra se manifestara de la forma más brutal. Hasta casi un mes después del desembarco no llegan a España imágenes de los acontecimientos de Anzio (63a) que se proyectan a la par que noticias sobre el cuartel alemán en Monte Cassino y escenas bélicas de defensas y ataques de ambos contendientes por campiñas y poblados. 
A mediados de marzo de 1944, Mussolini visita al nuevo embajador alemán y se omite cualquier otra información de Italia hasta dos semanas después en que las fuerzas aliadas del $5^{\circ}$ ejército y el $99^{\circ}$ aerotransportado norteamericanos y el $8^{\circ}$ británico, tras 26 dias de bombardeos, "disputan el terreno palmo a palmo en este sector" centroitaliano. A continuación podemos apreciar los avances tanto de la infantería como de la artillería nazi, sus reservas de municiones, baterías antiaéreas en Monte Cassino (65b, 66a). Quince días después parece que la guerra se ha detenido: sólo hay noticias de la Luftwaffe sobre los Apeninos, soldados que quitan nieve en los pasos de montaña o esquían en Noruega; los americanos practican el paracaidismo y los barcos pesqueros franceses salen a faenar protegidos por los alemanes. Pero, en realidad se avanza sobre Crimea, en el frente ruso se siguen devastando poblados y se han bombardeado ciudades alemanas y Londres.

Cuando se retoma la información, a principio de mayo de 1944, sobre Monte Cassino están cayendo " 2.500 toneladas de bombas en una milla cuadrada" según informan los norteamericanos. A su vez, los alemanes muestran como la ciudad ha quedado convertida en escombros: la abadia ha sido destruída (69b). Las fuerzas antiaéreas alemanas, la artillería pesada y ligera no ceja en la defensa y el ataque de todo el territorio (70a).

Para ambos contendientes la naturaleza dificulta las operaciones. EI deshielo convertirá los campos en barrizales intransitables (71b) y, para colmo, el Vesubio entra en erupción. Los aliados han de preocuparse no sólo de la guerra sino del fuego y la destrucción de los ríos de lava (75b).

Pero la guerra en Italia pasará a un segundo plano ante las noticias procedentes del desembarco de Normandía y el nuevo frente abierto en el Atlántico. Hasta mediados de septiembre de 1944 no vuelven a aparecer en las pantallas imágenes de Italia. Será para mostrar al rey de Inglaterra revistando a sus tropas en Nápoles así como a los polacos que participaron en Monte Cassino y Ancona (91b). Quince días después se verá la defensa alemana de Pisa y Rávena y, a continuación, los combates en Florencia del $8^{\circ}$ ejército hasta la entrada de los aliados en la ciudad (93b). Este reportaje prácticamente es coetáneo a los acontecimientos. A la semana siguiente se podrá ver la enorme cantidad de material transportado por el $7^{\circ}$ ejército en Nápoles (94b).

A partir de este momento y excepto alguna que otra información sobre la acción de las SS contra la resistencia en varios puntos de Italia (109a), una división alemana que dispara lanzacohetes contra unas ruinas defendidas por un tanque (111a), la vigilancia alemana en la frontera francoitaliana (113b), un viaje del Duce a Milán (119a) y, por último, el Papa 
recibiendo a los aliados $(124 a)^{6}$, en el NO-DO no aparecen más noticias de Italia.

Nunca se informó ni de la caída de Mussolini, ni de la constitución del nuevo gobierno dirigido por Pietro Badoglio, ni de la proclamación del armisticio y las represalias subsiguientes, ni de la huida del rey y la creación de la república de Saló o la declaración de guerra de Italia a Alemania. Tampoco se supo de la capitulación de las fuerzas alemanas en Italia, en abril de 1945, ni se vieron las imágenes que dieron la vuelta al mundo de Mussolini asesinado por los partisanos y colgado junto a Clara Petacci.

\section{c) El frente del Este}

Desde el noticiario número 1 al 99b existe en el NO-DO una sección dedicada exclusivamente a la guerra en Rusia. La situación que se presenta apenas varía a lo largo de los casi 100 números.

Al quedar las tropas alemanas embolsadas en dos zonas tras el cerco de Stalingrado y capitular el 31 de enero de 1943 las fuerzas del sur y el 2 de febrero las del norte con cerca de 90.000 alemanes prisioneros, las noticias que llegan son de los sectores de los frentes central y norte. En todo momento parece que los alemanes dominan a los rusos. Se ven imágenes de armamento destruído en el Cáucaso (18), la cliberación de la tenaza de hierro en San Petersburgo" donde se derrota a la artillería y se derriban aviones (19) además de luchar contra la nieve y el deshielo a lo largo de todo el período bélico.

La cabeza de puente del Kuban, su cañaveral, será otro de los centros de atención bélica. Bombardeos aéreos y terrestres (31a, 32b, 33b, 34b) muestran las posiciones alemanas. También en el mar Negro, donde se construyen refugios y los stukas bombardean sin cesar, dando la impresión de dominio alemán (32a, 52b). Otro centro de atención del informativo será Orel donde las comunicaciones y los puentes quedarán destruídos (38a, 38b).

Alemania intensifica su producción de armamento con destino al frente ruso $(28 a, 29 a)$. Los envites siempre van acompañados por lanzamientos que ocultan a las tropas y protegen los convoyes (29a). Los submarinos

También habia bendecido a los obreros de los cuerpos especiales alemanes en Roma (Organización Todt) y había condenado "las teorías subversivas del comunismo" (29a) en julio de 1943. 
atacan a los buques soviéticos (61b). En muchos reportajes los alemanes aparecen tranquilos, en las pausas del combate (52a), reparando el armamento (68a) o se muestra el aprovisionamiento del frente (65b). Aún a mediados de marzo de 1944 se dan noticias del «avance alemán" y la victoria en Crimea cuando, realmente, será evacuada al mes siguiente (69a). Quince días después informaciones de noticiarios americanos muestran el abandono de las columnas blindadas germanas (71a) ${ }^{7}$, aunque se siga dando informaciones sobre el envío de reservas a la zona de Leningrado, de convoyes al mar Negro, se derriban aviones bolcheviques -ahora imágenes llegadas de Alemania- (72b, 74b) y se libera las tropas situadas en Kurks, después de 25 dias de asedio (75b).

En septiembre de 1944 el NO-DO muestra la nueva línea defensiva soviética cerca de Vilna, vecina ya a la frontera polaca "para oponerse al avance bolchevique». La población civil se traslada con las tropas alemanas ya que "no quiere volver a sentir los horrores del comunismo" (89a). Por el sur la nueva frontera bélica se establece en la rivera del Dnieper (92b). Los soviéticos han recuperado hasta Kiev, pero los alemanes "siguen avanzando" (93a) y siguen llegando refuerzos.

A mediados de octubre de 1944, por primera vez se dirá en el texto que "los alemanes y húngaros resisten y los rusos avanzan» (99b). El discurso general mantiene la tónica del contraataque del Reich y rechazo de las ofensivas por la artillería (102b). En diciembre de 1944 todavía se construyen nuevas fortificaciones (104b) y los stukas destruyen más de 400 tanques bolcheviques (108b).

En estos momentos, en que está a punto de caer Budapest ya no se indican los frentes ni las zonas de guerra. Las imágenes del frente del Este son mucho más encarnizadas en las pantallas (105a, 105b, 106b), incluso se ve a la artillería americana que avanza por el Don (107a).

Los frentes italianos y después atlántico desviarán, en cierto modo, la atención sobre la zona rusa y, al retomar la información, desaparecen los enunciados de los reportajes del frente del Este. Se incluyen en otro bloque más general denominado "Reportajes de guerra" (100 a) en los que los alemanes "ponen todo su heroismo para resistir la ofensiva soviética" (116a). Se sigue remarcando que los alemanes luchan "contra la ofensiva soviética (...) y abren brechas en la base enemiga (...) a lo largo de los $1.000 \mathrm{~km}$. de frente" (118b). Pero ya la guerra para Alemania está

El texto tiene narración norteamericana. 
perdida, porque en estos momentos los aliados ya están estrechando la mano de los soviéticos en Torgau.

Las siguientes imágenes referidas a Alemania serán la liberación de prisioneros de los campos de concentración y el descubrimiento de los horrores de esta masacre (125a), el desarme de las tropas alemanas (126b), la entrega de los altos mandos (127a) y la firma de la rendición por parte de Von Friedeburg en el cuartel general de Montgomery (127b). Posteriormente los procesos de Nüremberg cerrarán la información.

\section{c) La guerra del Japón y del Pacifico}

Al resultar mucho más lejana de España la guerra del Pacífico, la información es más ajena que los acontecimientos de la guerra en Europa, y, por ello, es menor. En torno a 60 reportajes se ocupan de dar a conocer la situación, cantidad ínfima comparada con los cerca de 1.100 reportajes dedicados a todo el conflicto mundial durante los tres años y medio que abarca la información.

La guerra del Japón es, asimismo, parte de la lucha contra el comunismo. La invasión de la China roja en la zona de Yunann donde clos nipones aniquilan a los comunistas de la China de Chun Kin. Queda limpio El territorio de los últimos focos de inquietud" (15) es un ejemplo del discurso que se sigue durante todo el conflicto. Además, Japón se defiende «de la tenaza que le infligen los norteamericanos" invadiendo Borneo (1), Nueva Guinea —ocupación de Saramago y bombardeo de Puerto Darwin (23a)-, Birmania (32a)...

Se presenta a los japoneses como disciplinados gimnastas $(28 \mathrm{~b}, 33 \mathrm{~b}$, $60 a)$, que desfilan ante su emperador (1), visitan exposiciones en Viena (85a), y están hermanados con los alemanes (45b) - su embajador visita a Hitler (89b, 96b) - que tienen parte de su flota de submarinos en el Indico (55b, 63b), para ayudar a los nipones.

Por su parte los aliados son ayudados por los indígenas a defenderse en Birmania "de los beligerantes" (36b). Cuando ya ha tenido lugar la batalla del mar de los Corales y se ha detenido la expansión japonesa hacia el sur, a partir del verano de 1945, dará comienzo la gran ofensivá del Pacífico.

Excepto algunos reportajes del principio del NO-DO, la mayor parte de la información sobre esta zona del conflicto mundial llega desde Estados Unidos y, claro, se va viendo la victoria de los aliados. En diciembre de 1943 el NO-DO da la noticia de la "ofensiva más importante 
de las operaciones militares de los aliados" que está teniendo lugar en Birmania (51a, 60b, 72b),donde, todavía, en noviembre de 1944 "se han hecho fuertes las fuerzas japonesas" (95a), en enero de 1945 continúan los combates (104b). Las imágenes serán duras. Se ven muy cercanos los enfrentamientos, los lanzallamas, el avance de las tropas y la artillería ligera (58b).

A partir de estos momentos se ofrecen varios reportajes sobre la acción de los portaaviones en las islas Marshall $(60 a, 65 a)$ y combates en toda la zona del Pacífico (62b, 70a, 85b) para reconquistar las Aleutianas (64a), Nueva Guinea (56b, 57a), las islas del Almirantazgo -atacadas por sorpresa por Mac Arthur- (71a), Raboul (74b), las Marianas -la $5^{\text {a }}$ flota protege el asalto a Saipán, a 500 millas de Tokio- (88a), Guam "primer jalón hacia el Japón y Filipinas» (90a) -noticia dada en septiembre casi concluidas las operaciones-, el desembarco de marines y llegada de tropas aerotransportadas que avanzan hacia la capital totalmente devastada (95b, 97a). Los japoneses van siendo obligados a replegarse hacia sus territorios (72a) y, por fin, el general Mac Arthur regresa a Filipinas upara cumplir su palabra (...) y destruir 900 barcos japoneses» (102a, 108b).

Los B-29 comienzan sus incursiones sobre Tokio, la capital del imperio nipón, con 7 millones de habitantes. Desde las islas Saipan a $2.700 \mathrm{Km}$. de distancia salen miles de aviones para bombardear durante más de 2 horas (109b). Entretanto, en Birmania, los aliados intentan «impedir a los japoneses, con enormes esfuerzos, que lleguen a Mandalay" (110b).

Mac Arthur y las tropas del almirante Nimitz entablan grandes combates en Leyte para conquistar las Filipinas. Durante dos días la $3^{\mathrm{a}}$ y la $7^{\mathrm{a}}$ flota no cejan en la ofensiva (111a). La aviación no afloja en los bombardeos preparando la llegada del $6^{\circ}$ ejército, hasta conseguir la caída de Luzón (114b, 116a). Mac Arthur libera Manila y salva a los rehénes civiles que aún quedan con vida (124b). La 37 división acaba con la resistencia japonesa (134a).

Mientras tanto, la $14^{\mathrm{a}}$ división británica avanza hacia Mandalay construyendo en 26 horas un puente (111b). Tropas norteamericanas desembarcan en Birmania (114a). El paso ya es transitable. Se pueden enviar suministros desde la India a China (122b). La llegada de la 38 división, apoyada por las fuerzas aéreas, facilita la marcha de la infantería (127a). Se desfila triunfalmente una vez tomada Rangún (138a). Para entonces, Filipinas y Nueva Guinea ya han sido liberadas (121a).

40.000 soldados de la $5^{\mathrm{a}}$ división, 20.000 jeeps y 4.000 aviones se encuentran a $1.000 \mathrm{kms}$. de Tokio (123b). Comienza la ofensiva aérea, definida 
como una "proeza de valentía y organización». Mientras los americanos "perdieron 9 aeroplanos" han destruido " 571 aviones y 55 buques" japoneses (125b).Tokio y Okinawa son bombardeadas «el 90\% de los aviones japoneses caen al mar» (126a), "50.000 enemigos han muerto" (134a). Los buques británicos se unirán a los norteamericanos para concluir la guerra contra el Japón (137b). Por primera vez aparecerán en las pantallas los «kamikazes dispuestos a morir ante la derrota que les espera" (137b), aunque "la guerra extraña de los kamikazes causa muchas bajas, no aplazará la derrota del Japón" (141b). En el número siguiente se anuncia su capitulación (142a).

\section{LA GUERRA DE LOS ALIADOS}

Como ya se ha indicado, la información sobre los aliados tarda en aparecer en el NO-DO y es únicamente descriptiva, sin tomar posturas ideológicas. A mediados de 1944 solamente uno de cada 8 reportajes que componen cada número - y no de todos - se dedica a los aliados. En el apartado titulado «Reportajes de guerra» se va promediando la información de los frentes alemanes y de los diferentes conflictos abiertos en todo el mundo. Por lo general los reportajes proceden de Estados Unidos, aunque algunos sean de origen británico.

En un principio, muchos de los reportajes dedicados a los aliados no hacen referencia a la guerra en sí, sino a la evolución del armamento y la industria bélica que, por otra parte, también se ha mostrado respecto a Alemania. Baterías antitanques que "ayudaron a derrotar a los nazis en Salerno" (44a), autobuses gigantes para el transporte de 250 soldados (47a), aircraft que hacen recorridos de los aviones a los portaaviones (49b), barcazas que transportan jeeps (51b), portaaviones gigantes (59b), globos que protegen convoyes (70a), bombas de gran calibre (70b), aviones sin motor (73b), aviones B-25 que arrojan bombas con paracaidas (75b)... El transporte de tropas será otro tema a tener en cuenta. La cantidad de material y hombres que se moviliza es impresionante. En diciembre de 1943 se organizan 65 trenes con 1.300 vagones para la infanteria (47b).

Todo es válido para concienciar a la población del estado de guerra. El sistema de propaganda americano funciona tan bien como el alemán pero sus parámetros son diferentes. Si los nazis utilizan el esplendor de su bellos jóvenes desfilando ante el Fhürer, la grandiosidad del estado nazi, su arquitectura y escultura monumental, los americanos también utilizan sus 
bazas más espectaculares, las estrellas de cine: Clark Gable de servicio (50a), artistas de la pantalla se trasladan a Washington para vender bonos (52b), Robert Taylor se entrena como aviador (61b), Carole Lombard que muere en un accidente de aviación cuando se trasladaba para vender bonos de guerra (63a), etc.

Los animales tampoco son ajenos a la situación: perros que son adiestrados en el salvamento de heridos, transporte de municiones, saltos en paracaidas (53b), elefantes que transportan maderas y cañones (59b). No hay que pasar por alto la labor de las mujeres en la guerra, lo que llama la atención a los redactores del NO-DO: mujeres que construyen barcos, aviones, tanques y ¡los manejan! (41a, 50a, 55a).

Los reportajes llegados desde Estados Unidos también hacen referencia a los paises alineados a la causa de los aliados: un desfile en Brasil "dispuestos a ocupar su puesto en ultramar al lado de los aliados" (44a), sus explotaciones de caucho y minerales "tan importantes para la guerra" (55b), la acogida de prisioneros de los campos japoneses (59a); Canadá que participa con su cuota maderera...

En realidad toda una gran nación y sus satélites están preparándose para la gran ofensiva. Si hasta el comienzo de la invasión de Normandía se han tratado en los noticiarios estos temas laterales, a partir de la llegada a Normandía los reportajes sobre el avance en Europa será el centro de atención del NO-DO.

Por supuesto que los alemanes han "terminado las medidas para hacer frente a la invasión" - la cámara muestra fortificaciones de cemento inexpugnables, artillería pesada, alambradas, etc.-, noticia que se da la tercera semana de junio de 1944. En el mismo número de NO-DO paracaidistas norteamericanos se preparan para lanzarse y el texto anuncia "el comienzo de la invasión" (76b).

Todas las imágenes de los siguientes reportajes del noticiario serán de unidades británicas y norteamericanas dispuestas a llegar a Europa. «Ha llegado el dia $\mathrm{D}$ y la hora $\mathrm{H}$ ", rezarán los textos del NO-DO. Barcos y barcazas desembarcando jeeps y artillería mientras la infanteria pone sus pies en las costas francesas al mando de Montgomery e Eisenhower (78b).

Tampoco fue un paseo militar. Los alemanes resisten y se oponen a las vanguardias (80a). Los aliados avanzan hacia Rouen y lanzan proyectiles a Calais, mientras los alemanes bombardean Londres (82a), Avignon, Isigny... es dura la lucha en los distintos centros de población, muchos hombres caen heridos. Siguen llegando tropas a Normandia (83b-85a). 
Se investigan nuevas armas, los alemanes prueban el torpedo humano y los $\mathrm{V}-1$, los norteamericanos, las bombas incendiarias (86a).

Nada es todavía definitivo, aunque a partir del atentado que Hitler sufre en su cuartel general (87b) y aunque las columnas alemanas sigan marchando por Francia, hay en los textos cierto derrotismo que se expresa en frases como «cumplidos los objetivos, las columnas [alemanas] inician la retirada" (87b).

El triunfalismo de la palabra y de la imagen se va volviendo hacia los aliados. 11.000 aviones, 31.000 soldados y $5.000 \mathrm{Tn}$. de explosivos se han acumulado antes de la llegada a Cherburgo. Una instalación de los $\mathrm{V}-1$ ha sido destruída. Caen es ocupado (88a). Alemania ordena la movilización total mientras París es liberado. Guam ha caido en el Pacífico y el $8^{\circ}$ ejército británico está cerca de Florencia. Churchill se entrevista con Roosvelt en el Canadá (94b). Rommel ha muerto (95b) y los aliados llegan a la frontera alemana a la vez que desembarcan en Holanda (96b).

Durante todos estos números del NO-DO, la redacción se va decantando hacia los aliados. Ahora ya hay más informaciones de este lado que de Alemania, diferencia que va pasando del doble al triple o al cuádruple. Al igual que al principio del NO-DO se veían imágenes de la vida alemana, ahora serán de todo lo referente a Estados Unidos y los paises de su órbita.

El transcurrir del conflicto se va viendo a través de los distintos números del noticiario. La "evidente ventaja de los aliados" cambia la cara del NO-DO. El trabajo de los cámaras norteamericanos también es distinto a las noticias enviadas desde Alemania. Predominan los planos más cortos tanto de los asuntos bélicos como los temas referentes a políticos. Se ven los rostros de los que serán los responsables del nuevo orden mundial, mientras que antes existía una mayor distancia de los «héroes» fascistas.

Durante los siguientes treinta números del NO-DO, la guerra seguirá en la cumbre informativa del noticiario, hasta que por fin en el número $124 \mathrm{~b}$ se da la noticia de "Europa en paz", pero ¿a qué precio? Campos de tumbas, zanjas de kilómetros con cadáveres (125a), ciudades destruídas, campos arrasados, millones de refugiados y prisioneros, juicios... y para terminar, Hiroshima y Nagasaki «otra prueba para el enemigo del producto de la guerra” (151b).

Estas palabras podrian servir de cierre para seis años de contienda mundial. El miedo se usará como disuasión para detener futuros posibles enfrentamientos, aunque el nuevo orden mundial y las señales del dolor sufrido serán el freno, sólo por poco tiempo, de próximos conflictos bélicos. 